NIPER-606

Distribution Category UC-122

\title{
Estimates of Future Regional Heavy Oil Production at Three \\ Production Rates--Background Information for Assessing \\ Effects on the U.S. Refining Industry
}

\author{
Topical Report \\ By \\ David K. Olsen
}

July 1993

Work Performed Under Cooperative Agreement No. DE-FC22-83FE60149

Prepared for

U.S. Department of Energy

Assistant Secretary for Fossil Energy

Thomas Reid, Project Manager

Bartlesville Project Office

P. O. Box 1398

Bartlesville, OK 74005

Prepared by

IIT Research Institute

National Institute for Petroleum and Energy Research

P.O. Box 2128

Bartlesville, OK 74005

MASTER 


\section{TABLE OF CONTENTS}

Page

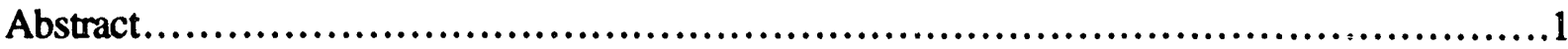

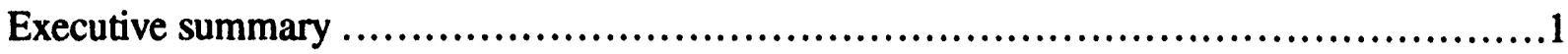

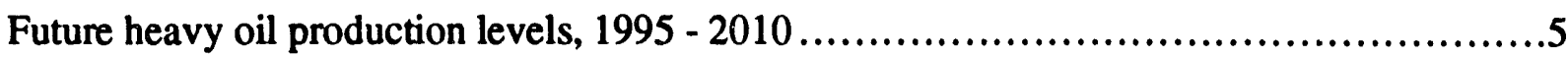

Current levels of domestic heavy oil production ...................................6

Previous projections of heavy oil productivity ...................................8

Projected oil production levcls, location, and volume of future heavy oil ............... 12

Case 1. "Free market" scenario: Heavy oil development following current trends in the economy, politics, and the oil patch........................ 14

General discussion for case 1 ...................................... 15

High production level ............................................. 16

Mid-level production ............................................... 16

Low production level............................................... 17

Case 1 regional effects .............................................. 18

Case 2. "Managed market" scenario: Heavy oil development following legislation that encourages domestic production. A major political and economic change affecting the oil patch................................23

General discussion for case 2 ....................................... 23

Case 2 regional effects ............................................... 25

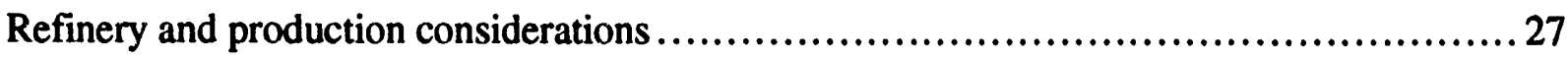

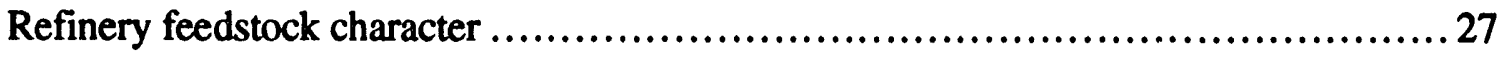

Refinery trends and changing oil product requirements...................................... 30

California oil production experience and outlook................................... 31

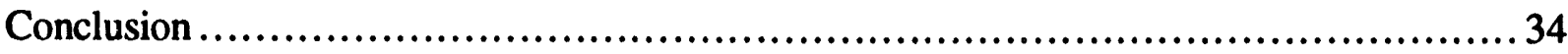

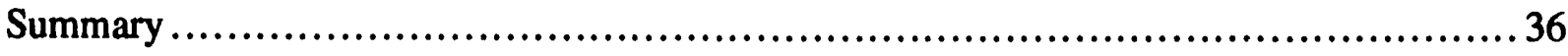

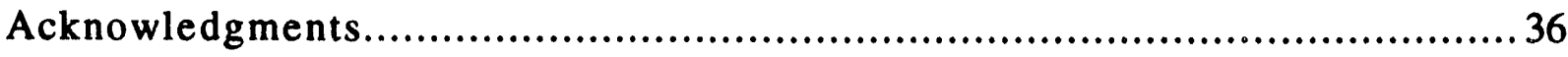

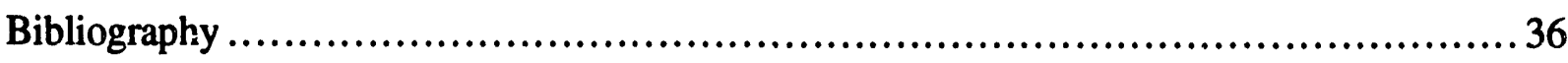




\section{TABLES}

Page

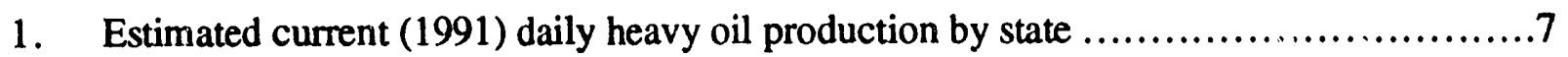

2. Average Annual Crude oil prices of the past decade............................................ 12

3. Projected heavy oil production levels and time frames for an additional

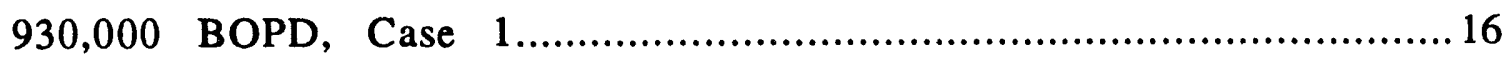

4. Projected heavy oil production levels and time frames for an additional

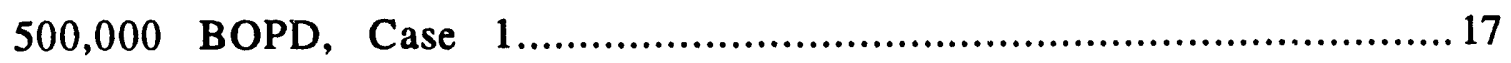

5. Projected heavy oil production levels and time frames for an additional 300,000 BOPD, Case 1............................................................. 18

6. Projected heavy oil production under the second set of assumptions, Case 2.............25

7. Composition of projected heavy oil ........................................... 35

\section{ILLUSTRATIONS}

1. Map of the United States showing principal heavy oil field locations and Petroleum Administration for Defense Districts (PADDs) boundaries.............................6

2. Projected production rates for thermally produced oil from 1984 NPC study ............9

3. Projected sensitivity of thermal recovery production rate to nominal crude oil price .......9

4. Kern River $13^{\circ}$ API posted price per barrel..................................................11

5. Oil price per barrel for representative U.S. crude oils........................................ 11

6. Map of United States showing heavy oil field locations ............................. 19

7. U.S. crude oil consumption, domestic oil production, and imported crude and

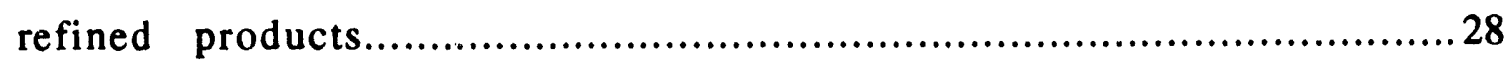

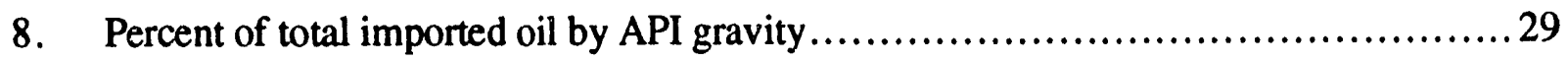

9. U.S. refinery crude feedstock API gravity and sulfur content ........................30

10. California oil production since 1940 showing the percent of total oil that is heavy oil... 32

11. Total oil production by regions within California............................................. 33 


\title{
ESTIMATES OF FUTURE REGIONAL HEAVY OIL PRODUCTION AT THREE PRODUCTION RATES-BACKGROUND INFORMATION FOR ASSESSING EFFECTS ON THE U.S. REFINING INDUSTRY
}

\author{
By David K. Olsen
}

\begin{abstract}
This report is one of a series of publications from a project considering the feasibility of increasing domestic heavy oil ( $10^{\circ}$ to $20^{\circ}$ API gravity inclusive) production being conducted for the U.S. Department of Energy. The report includes projections of future heavy oil production at three production levels: 900,000; 500,000; and 300,000 BOPD above the current 1992 heavy oil production level of 750,000 BOPD. These free market scenario projections include time frames and locations. Production projections through a second scenario were developed to examine which heavy oil areas would be developed if significant changes in the U.S. petroleum industry occurred. The production data helps to define the possible constraints (impact) of increased heavy oil production on the U.S. refining industry (the subject of a future report). Constraints include a low oil price and low rate of return. Heavy oil has high production, transportation, and refining cost per barrel as compared to light oil. The resource is known, but the right mix of technology and investment is required to bring about significant expansion of heavy oil production in the U.S.
\end{abstract}

\section{EXECUTIVE SUMMARY}

This report is one of a series of publications considering the feasibility of increasing domestic heavy oil $\left(10^{\circ}\right.$ to $20^{\circ} \mathrm{API}$ gravity) production. This report summarizes projected patterns in heavy oil production at three future production rates under a free market scenario which includes time frames and locations. In addition, a managed market scenario such as imposed by a significant import fee, was used to determine production levels and locations but without time frames in an effort to examine which heavy oil areas would be developed if significant changes in the U.S. petroleum industry occurred. These projections were developed based on upstream factors such as the known amount and field location of heavy oil resources, reservoir and crude oil characteristics, and basic production economics relative to downstream factors such as pipeline and refinery capacities and locations. This report provides heavy oil production forecast/background data that was compiled in late 1991 for a nationwide study analyzing the impact of increased heavy oil production on the U.S. refining industry.

Heavy oil resources exist in the U.S. and the technology is available to develop much of the resource, but some heavy oil resources are more economically produced than others. One of the major market constraints for the development of the resource is oil price. Heavy oil sells for less 
per barrel than light oil (there is a price reduction for sulfur and API gravity), and production, transportation, and refining costs significantly more per barrel. In a free market, refiners are free to purchase higher quality domestic or imported light and medium crude oils that as a rule have fewer production, transportation, and refining problems than either foreign or domestic heavy oil. In a free market, investment opportunities in other countries look good with unlimited ability to import oil to the U.S. Rates of return on investment in other parts of the world for development of liquid energy resources (light, medium and heavy oil) are often higher than in the U.S. in spite of the risks within a country for nationalization. The target reservoirs are often larger, and modern technology can be used to develop and manage the resource. This has caused a growing capital shift of investment resources from the U.S. to these areas. If the U.S. heavy oil resource is to be developed, incentives for production, transportation, and refining will be needed. A major increase in heavy oil production would reduce the projected rate of decline in U.S. oil production, but the decline in the development of U.S. light oil resources will have to be arrested as well. Otherwise, the U.S. will continue to increase imports of oil to meet demand. Development of the U. S. heavy oil production, transportation, and refining infrastructure, if accompanied by the proper incentives, could create a substantial number of jobs and profitable investment opportunities in the U.S.

Projections of heavy oil production increases have been developed, based on analysis of U.S. heavy oil resources, their producibility, the pipeline network and existing refining capacity. These projections were made as to the volume, location and possible time frame for expansion of the heavy oil industry in the U.S. Current heavy oil production in the U.S. is about 750,000 BOPD, $11 \%$ of the 7,000,000 BOPD domestic production (World Oil, 1993). The largest incremental increase addressed by NIPER is the high volume case projected by Brashear, Godec and Wood (1991). This projection of 930,000 BOPD of additional heavy oil was part of the overall light and heavy oil production target of the 1991 National Energy Strategy (NES), (NES, 1991). Producing areas and volumes projected to fill the production target were first examined. Since it would take a major national commitment to develop the scale of effort necessary to achieve 930,000 BOPD, more realistic volumes of 500,000 BOPD (same volume scale as current thermal heavy oil production in California which has taken 30 years to develop), and 300,000 BOPD (an achievable volume but will require great effort) were considered. Previous projections of thermally produced oil (mostly heavy, but some light) have ranged as high as $2,000,000$ BOPD (total) by advanced thermal methods with nominal oil prices of $\$ 30 / \mathrm{bbl}$ (1983 constant dollars, National Petroleum Council, 1984, p. 77).

Within these projections, California has the greatest heavy oil resource but expansion is limited by a saturated oil market, principally controlled by majors and strongly influenced by Alaskan light oil production (Olsen, Ramzel and Pendergrass, 1993). Alaska has the second 
greatest heavy oil resource but production and transportation are very expensive, and this heavy oil will likely have to be processed in the lower 48, where it competes with California heavy oil. Wyoming has heavy oil in deeper formations that have only partially been developed on wide spacing with primary and limited secondary production. However, the Rocky Mountain states have little refining ability to process heavy oil. Midcontinent heavy oil reservoirs are Pennsylvanian (300 million years in age as compared to most Californian heavy oil reservoirs which are Tertiary Age or about 60 million years old) and for the most part have been extensively altered (diagenesis) from their original unconsolidated nature. This has resulted in cemented, compartmentalized, low permeability reservoirs that have little future economic prospects for heavy oil production even with EOR. The Midcontinent is not expected to contribute significant future heavy oil.

The remaining area with significant heavy oil production potential is the U.S. Gulf Coast. Future heavy oil will come from Tertiary Age (younger sands 67 to 4.6 million years in age) unconsolidated sands or friable sands. Except in select areas, the Gulf Coast heavy oil resource has not been developed because there has been ample light oil in the region. The unconsolidated Gulf Coast reservoirs are more like California heavy oil reservoirs than those of other areas of the Nation. The region has light oil available for dilution for pipeline transport, and the Gulf Coast has refining capacity and bottoms processing units required to process heavy oil.

The 1992 domestic heavy oil production was approximately 750,000 BOPD with approximately 460,000 BOPD attributable to thermal production (cyclic steam, steamflood, or in situ combustion) (Moritis, 1992). Thermal production represented $61 \%$ of all U.S. EOR production ( $761,000 \mathrm{BOPD}$ ) in 1992 . California contributes nearly $98 \%$ of the thermally produced oil, and heavy oil contributes over $70 \%$ of California's total oil production (Mefferd, 1988, 1989, 1990; Olsen, Ramzel and Pendergrass, 1992, 1993).

Two projected (not forecast) production scenarios, designed to test the difficulty in achieving increases in domestic heavy oil production, are included in this report. The Case 1 "free market" scenario is based on generally more realistic assumptions as compared to a Case 2 "managed market" scenario. The latter primarily reflects the assumption of government imposition of regulations causing imported crude oil and/or refined products to cost twice that of domestically produced oil and/or products. Case 1 sets the assumptions for making domestic projections of potential future heavy oil production, including time frames and locations, at three production levels: 900,$000 ; 500,000$; and 300,000 BOPD above the current 1992 heavy oil production level of 750,000 BOPD. Case 2 sets the assumptions for making domestic projections of potential future heavy oil production to examine which heavy oil areas would be developed if significant changes in the U.S. petroleum industry occurred. Case 2 scenario examines the maximum amount of heavy oil the U.S. could produce. All oil production estimates in Case 1 and 2 scenarios are 
based on NIPER's analysis of the U.S. regional heavy oil resource and anticipate heavy oil selling for two-thirds of the EIA projected light crude oil prices in the years 2000 through 2010 (EIA, 1991).

Results of the "free market" scenario show that the lower production level (an increase of 300,000 BOPD) is the easiest to achieve. Because of its large heavy oil resource and heavy oil production and processing infrastructure, this goal may be more easily achieved in California, in spite of its currently oversupplied market due to projected declines in Alaskan North Slope (ANS) production. Development of heavy oil in the Gulf Coast from unconsolidated/friable sandstone formations would be the next easiest. At higher production levels, emphasis would shift more to the Gulf Coast. Production of heavy oil from Alaska will be small compared to Califor nia or the Gulf Coast. Additional heavy oil refining capacity would be required at all production levels.

In the "managed market" scenario, using drastically restructured U.S. energy policy (high oil import fee), the analysis illustrates that even marginal heavy oil resources are producible, but the better heavy oil resources and nearly all light oil resources will be developed first. Alternate energy resources (gas, coal, geothermal, solar, wind, etc.) would be developed, and conservation would be emphasized as the petroleum resources are developed. There would be a reduction in the foreign trade deficit and large-scale investment in the U.S. energy infrastructure would occur.

Significant economic barriers exist in achieving these higher heavy oil production levels. These barriers exist in each industry segment: production, transportation, and refining. In California, for example, the oversupplied heavy oil market is the result of several factors: (1) It has a large heavy oil resource. (2) It has a large heavy oil production and processing infrastructure. (3) There is a restriction that Alaskan North Slope, $27^{\circ}$ API gravity oil be refined and used in the U.S. Since ANS is light oil and California is the largest, most convenient light fuel market (i.e.-gasoline, diesel, etc.), most ANS goes to California. (4) The cost of transporting excess heavy oil outside the state to refineries with the capability to process heavy oil is high. (5) Investment capital is limited and there are numerous opportinities outside the U.S. for investment in the petroleum industry that may have a higher rate of return than heavy oil. Since declining ANS production will probably be replaced in part by imports of South American or Pacific Basin light and medium crude, California's situation may not drastically change in a "free market".

In California, the benchmark Kern River heavy ( $13^{\circ}$ API gravity) has historically sold for from $50 \%$ to $70 \%$ of West Texas Intermediate (WTI) oil price. In other areas of the country where oil composition and oil markets are different, the penalty for API gravity and sulfur is less (the differential in oil price is less between heavy oil and WTI). The cost of heavy oil extraction (mostly steam) is high compared to most light oil extraction due to the long-term investment in heat required to reduce the viscosity of heavy oil. Long-term investment in heat (thermal energy) is 
required, and cyclic oil prices, especially at low oil prices, lead to instability and weak investment in developing heavy oil resources.

Heavy oil resources exist in the U.S., and technology is available to develop much of the resource. Some heavy oil resources are more economically produced than others. One of the major market constraints for development of the U.S. heavy oil resource is oil price. In a free market, refiners are free to purchase higher quality domestic or imported light and medium crude oils that have fewer production, transportation, and refining problems than either foreign or domestic heavy oil. Investment opportunities in other countries for the development of light, medium and heavy oil are yielding a better rate of return on investment and may have less future liability associated with future production. This has caused a growing shift of investment capital from the U.S. to these areas.

If the U.S. heavy oil resource is to be developed, incentives for production, transportation, and refining are needed. A major increase in heavy oil production would reduce the projected rate of decline in U.S. oil production. Otherwise, the U.S. will continue to increase imports of oil to meet demand. Development of the U. S. heavy oil production, transportation, and refining infrastructure, if accompanied by the proper incentives, could create a substantial number of jobs and profitable investment opportunities.

\section{FUTURE HEAVY OIL PRODUCTION LEVELS, 1995 - 2010}

The objectives of the nationwide heavy oil resource development study, including this report, are (1) to investigate from secondary data the known heavy oil resources, (2) to screen this resource for potential thermal or other EOR techniques, and (3) to evaluate various economic facets (refining, transportation, environmental, etc.) that may impact expansion of heavy oil production. This segment of the feasibility study was undertaken following a preliminary production study (Olsen, Johnson and Ramzel, NIPER-521, 1990) and a refining investigation (Olsen and Ramzel, 1991, 1992) which summarized some of the factors affecting the future expansion of domestic heavy oil.

The methodology used in developing the heavy oil production levels, time frames, and locations followed a "pragmatic" approach to fulfill production targets and to determine the potentials for development. The locations of the heavy oil resource, most reservoir properties and oil composition are known. Transportation capacities and volumes of diluent available for pipeline transport of heavy oil to a refinery capable of processing it, as well as the location and capacity of units at refineries are also known. Costs of competitive crudes at a refinery are proprietary. The schedules for development, both for new or additions to current production are subjective and were used to fulfill production targets. This report was initially based on a series of internal NIPER memorandums written during December 1991 and January 1992 which developed heavy oil 
production levels, including locations and time frames, in anticipation of Bonner \& Moore Management Science (Houston petroleum refining consulting company) using this data for crude feedstock estimates for their part of an assessment of refining industry capacity needed to handle additional U.S. heavy oil production. Select figures have been updated to reflect recent data.

\section{Current Levels of Domestic Heavy Oil Production}

Heavy oil, as used in this study, is defined as having gas-free viscosity of $>100$ and $<10,000$ MPas (centipoise, $\mathrm{cP}$ ) inclusive at original reservoir temperature or a density of $943 \mathrm{~kg} / \mathrm{m}^{3}\left(20^{\circ}\right.$ API gravity) to $1,000 \mathrm{~kg} / \mathrm{m}^{3}\left(10^{\circ}\right.$ API gravity) inclusive at $15.6^{\circ} \mathrm{C}\left(60^{\circ} \mathrm{F}\right)$ (Group, 1981). Figure 1 shows a map of the U.S. with heavy oil producing areas and Petroleum Administration for Defense Districts (PADDs) boundaries. Table 1 shows NIPER's estimates of 1991 domestic heavy oil production. NIPER's analysis of heavy oil reservoir data for states outside California indicates that previous estimates of heavy oil resources (Dietzman et. al., 1965; Kujawa, 1981; Interstate Oil Compact Commission, 1984; Crysdale and Schenk, 1990, Piper et. al., 1983) included significant light oil because data included total field production rather than production for only heavy oil reservoirs. Based on these analyses, the remaining U.S. heavy oil resource was adjusted by NIPER to 80 to 90 billion bbl. Of the U.S. heavy oil, California has by far the most with about 60 billion bbl, with Alaska suspected of having 5-20 billion bbl and the Gulf

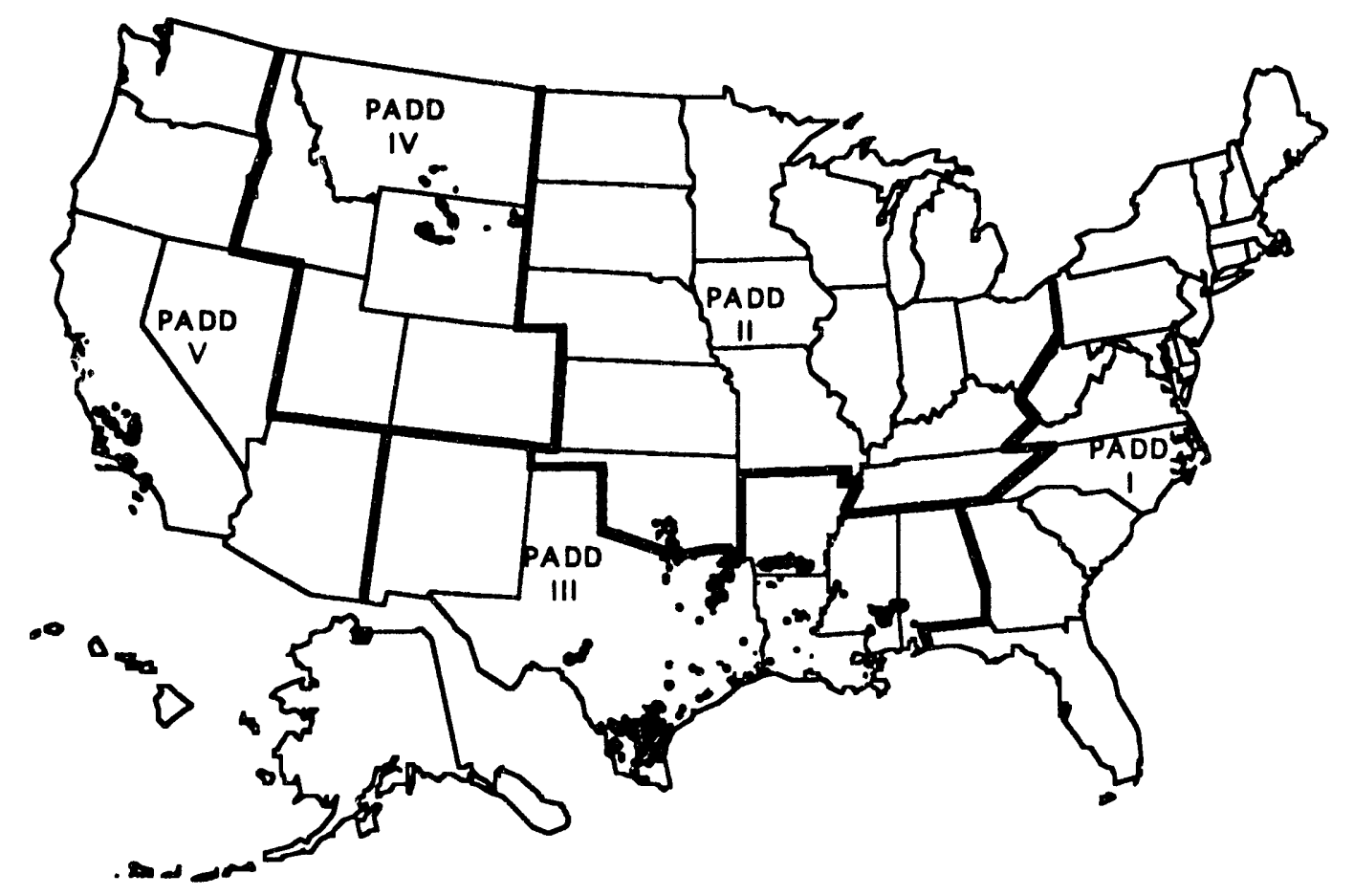

FIGURE 1. - Map of the United States showing principal heavy oil field locations and Petroleum $\Lambda d m i n i s t r a t i o n$ for Defense Districts (PADDs) boundaries. 
TABLE 1. - Estimated Current (1991) Daily Heavy Oil Production by State

\begin{tabular}{lrc}
\hline State & $\begin{array}{c}\text { Daily heavy oil } \\
\text { production, } \\
\text { bbl }\end{array}$ & $\begin{array}{c}\text { Source } \\
\text { of } \\
\text { data }\end{array}$ \\
\hline Alabama & 990 & $(1)$ \\
Arkansas & 11,300 & $(2)$ \\
Califomia & 655,700 & $(3)$ \\
Kansas & 964 & $(4)$ \\
Louisiana & 11,085 & NIPER estimate \\
Mississippi & 9,055 & $(5)$ \\
Missouri & 16 & $(6)$ \\
New Mexico & 2,000 & NIPER estimate \\
Oklahoma & 3,200 & NIPER estimate \\
Texas & 29,530 & $(7)$ \\
Wyoming & $>18,250$ & $(8,9)$ \\
PADD 1 all of East Coast & 0 & NIPER estimate \\
PADD 2 except states above & $<250$ & NIPER estimate \\
PADD 4 except Wyoming & 2000 & NIPER estimate \\
Alaska & $>3,000$ & $(10,11)$ \\
All other & $<1,000$ & NIPER estimate \\
\multicolumn{1}{c}{ TOTAL $\quad$ approximately 750,000} & \\
\hline
\end{tabular}

1 Petroleum Industry in Alabama, 1988, Alabama State Oil and Gas Board, pp. 47-65.

2 Annual Oil and Gas Report 1988, State of Arkansas Oil and Gas Commission, 1988 pp. $20-57$.

3 Conservation Committee of California Oil and Gas Producers, Annual Review of California Oil \& Gas Production 1991, Table B11-a, p. B-17. Includes offshore from State and Federal waters.

${ }^{4}$ Kansas Geological Survey, 1988 Oil and Gas Production in Kansas, pp. 2-183.

5 Mississippi State Oil and Gas Board, 1989 Oil and Gas Production Annual Report, pp. 35-85.

6 Personal communication, letter from J. C. Jaquess of the State of Missouri, Department of Natural Resources listing heavy oil by lease in Missouri, July 15, 1991.

7 Texas Railroad Commission, 1989 Oil and Gas Report, Vol. 1, pp. II-1 - II-331.

8 Wyoming Oil and Gas Conservation Commission, Oil and Gas Statistics for 1989, pp. I-1 - I-100 and VI-2 - VI-23.

9 Estimation from NIPER heavy oil database of Wyoming reservoirs as of 12/23/91 totaling 18,250 BOPD excluding about 12 reservoirs whose production has not been determined to date.

10 Personal communication with State of Alaska Oil and Gas Commissioner, August 1991.

11 Personal communication with State of Alaska, Department of Natural Resources, Oil \& Gas Division, Individual Well Production for 1991 for Conoco Milne Point Unit, as 2,770 BOPD for first 9 months of 1991 and increasing.

Coast states and Wyoming having most of the rest. California is by far the major heavy oil producer, followed by the Gulf Coast states of Texas, Louisiana, Mississippi, and Arkansas. The Gulf Coast production is about $10 \%$ the level of California's production. Wyoming is the remaining heavy oil producer with about 3\% of the total. Except for Alaska, these totals follow the regional resource pattern for heavy oil. Alaska is producing small but increasing volumes of heavy oil from the Milne Point field (Olsen, Taylor and Mahmood, 1992). 


\section{Previous Projections of Heavy Oil Productivity}

In 1984, the National Petroleum Council (NPC) published a study on the potential of Enhanced Oil Recovery in the U.S. (National Petroleum Council, 1984). The study concluded that EOR could significantly contribute to the Nation's future domestic crude oil supply. However, the study cautioned that "this potential is highly dependent on a broad spectrum of economic, technological, and policy considerations and constraints, which will require the concerted attention of both industry and government in order for the nation to realize the benefits of this resource."

The NPC study made projections of thermal oil production in the U.S. (mostly heavy oil), and these projections are shown in Figs. 2 and 3. Figure 2 shows oil projections using thermal oil production technology for both implemented (i.e.-current state-of-the-art) and advanced technology with $\$ 30 / \mathrm{bbl}$ oil. Figure 3 shows the case for thermal oil production using 1983 implemented technology under a variety of oil prices (constant 1983 dollars). Advanced technology includes steam foams for mobility and profile control, insulated tubulars and other advanced heat management methods, gas-fired steam generators, and cogenerators. The 1984 NPC study adjusted oil prices for the difference in API gravity between the nominal $40^{\circ}$ API gravity oil (nominal oil price as used in the NPC figures) and heavy oil price (NPC, 1984, p F-7 and F-8). The NPC study did not anticipate the low oil prices that were experienced in 1986-87 and 1989. Low oil prices have contributed to weak investment in heavy oil production, with some exceptions by major oil companies in California. These exceptions include investments made by several vertically integrated major oil companies (i.e., possessing their own heavy oil resources, production technology, heated pipelines, California refinery capacity to handle refining heavy oil, and service stations to market their transportation fuels) (Gill, 1990).

Recently, projections by Brashear, Godec and Wood (1991) indicated that with implementation of advanced EOR technology and an expanded oil research and development program, thermal oil production (primarily heavy oil) could be increased by an additional 930,000 BOPD. This projection was part of the 1991 NES target (National Energy Strategy, 1991). For heavy oil production to be economic, it must not only be efficiently produced, but it must have supporting infrastructure downstream, including heated pipelines or adequate light oil diluent to transport the heavy oil to a refinery designed to process heavy oil. Both transportation and processing entities must make an acceptable rate of return on processing heavy oil, or they will either take on medium and light oil (domestic or imported), reduce capacity, or close (Grigsby, 1990; Olsen and Ramzel, 1991; Olsen, Ramzel, Pendergrass, 1992).

To achieve the projected thermally produced oil production rate forecast in the 1984 NPC study, heavy oil production in California and the Gulf Coast States would have to increase significantly (Olsen, Johnson, Ramzel, January 1991). Achieving the projected goals in the NPC 


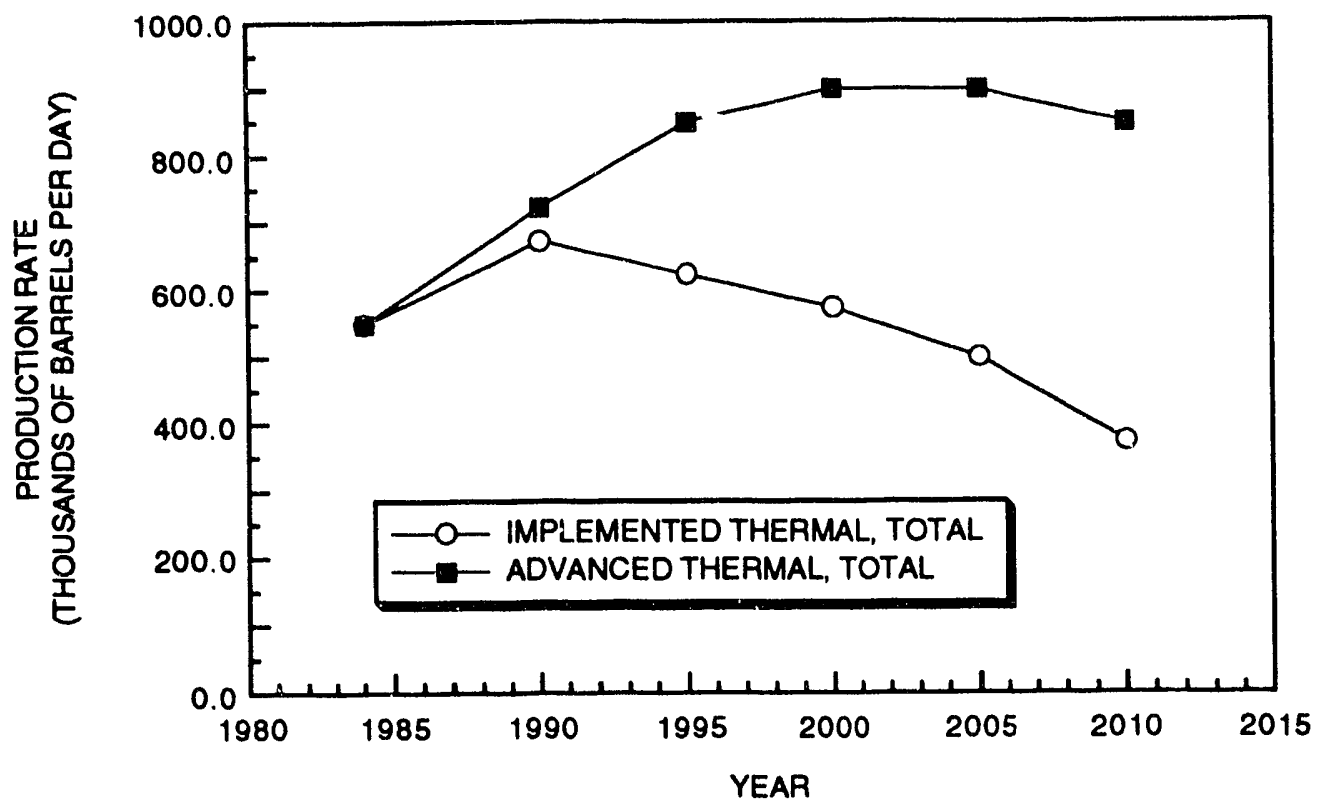

FIGURE 2. - Projected production rates for thermally produced oil from the 1984 NPC study. Comparison of implemented and advanced technology rates-at $\$ 30 / b b l$ nominal oil price and $10 \%$ minimum rate of return.

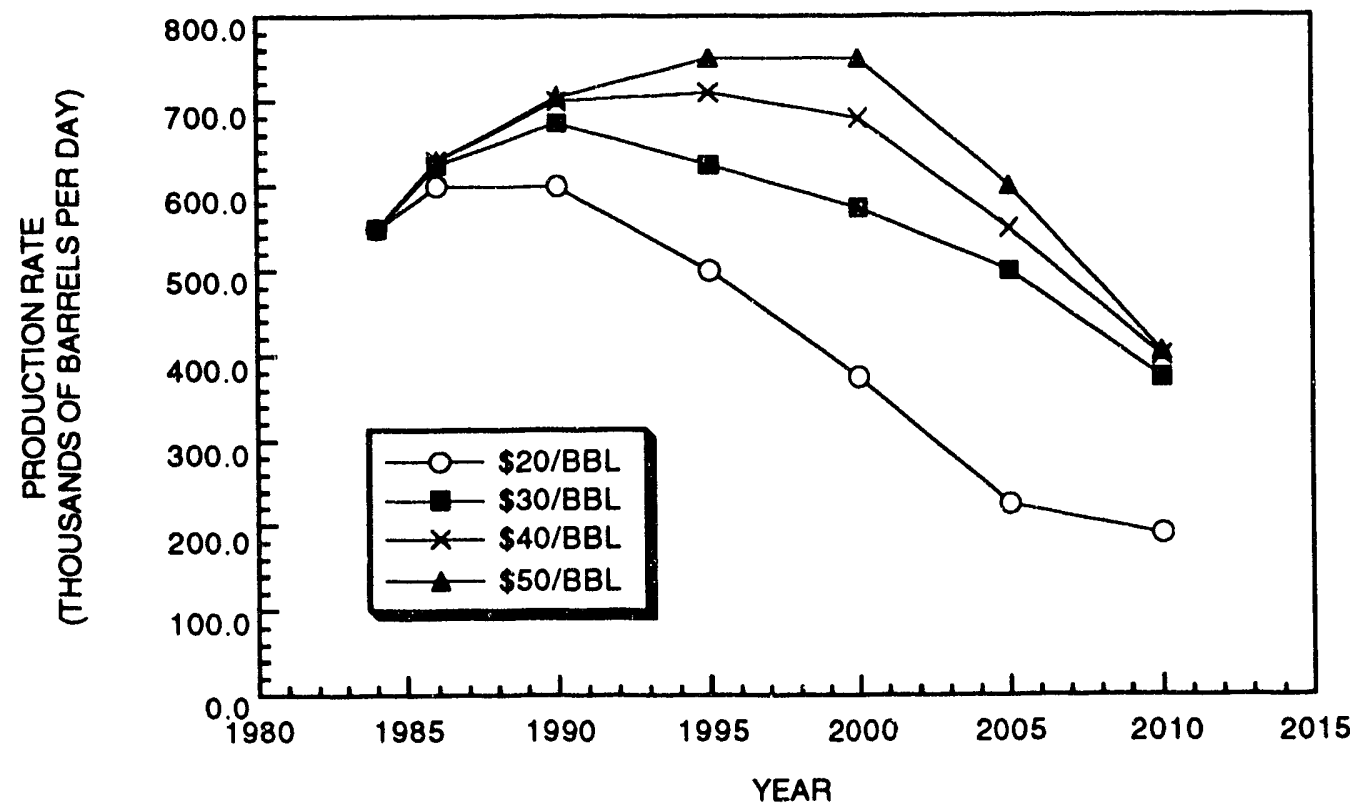

FIGURE 3. - Projected sensitivity of thermal recovery production rate to nominal crude oil price (constant 1983 dollars with $10 \%$ minimum rate of return) from the 1984 NPC study - implemented technology. 
advanced technology case at $\$ 30 / \mathrm{bbl}$ is doubtful in view of the oil production and low oil price trends (within California, the U.S. and the world) over the last few years. The 1984 NPC study cautioned:

"...(although) the study was conducted by experts in the field of enhanced oil recovery and other specialists from the petroleum industry, the resulting ultimate recoveries and production rate projections are nonetheless subject to a great deal of uncertainty. Comprehensive studies tend to converge on a best estimate answer. The shortcomings of such a rigorous approach is not what is included in the analysis but the uniknowns that are either outside the scope of investigation, or that cannot be precisely determined. These factors lie in the areas of economics, technology, and methodology. While there are a great many factors that may contribute to the overall economic uncertainty, oil price is considered the most significant" (National Petroleum Council, 1984).

The oil pricing and base case in the 1984 NPC study used:

"Both present (1983) and anticipated oil prices (which) substantially affect EOR activity. The results of the $\$ 30$ per barrel base case are strongly influenced by the events that occurred from 1978 to 1982 , when the real price of oil approached $\$ 40$ per barrel and was projected to rise even higher. EOR projects benefited and gained much momentum during this time, as shown by the substantial investments made to develop $\mathrm{CO}_{2}$ resources and pipeline systems to serve the miscible flood projects in the West Texas area. Also, expansions were made to most of the large steamflood projects in California. This increased activity became part of the ongoing EOR base on which the study results are constrscted" (NPC, 1984).

Concurrently with expansion of the California steamflood projects, major investments in heavy oil upgrading capacity were undertaken by several California refineries.

A best correlation of actual 1990 thermal oil production of 495,300 (Conservation Committee of California Oil Producers, 1991) versus projected performance in the 1984 NPC study occurs under the implemented thermal technology and $\$ 20$ per barrel oil scenario as shown in Fig. 2 . The approximate projection of 600,000 BOPD shown in Fig. 3 is about 100,000 BOPD higher than 1992 annual thermal production of heavy oil in the U.S of which $99 \%$ is California TEOR production (Moritis, 1992). The posted price (Fig. 4) for Kern River oil, 13 API gravity which is the benchmark California heavy oil has been substantially lower than the lowest price scenario considered in the 1984 NPC study.

The dramatic drop in oil prices in 1986 and market volatility is illustrated in Fig. 5 for some world benchmark crude oils with Alaskan North Slope (ANS) oil quoted on the North Slope. Table 2 shows oil prices and ratios of oil prices between West Texas Intermediate (WTI), and Kern River heavy oil (Maples, 1993). The oil price per barrel has generally trended upward since 1988 but has been highly volatile. Kern River has averaged about two-thirds of the price of WTI during much of the past decade. Heavy oil has historically (previous 25 years) sold for about $\$ 5 / \mathrm{bbl}$ less than WTI, but the price gap has expanded to about $\$ 7 / \mathrm{bbl}$ since the 1987-1988 drop in oil prices. 


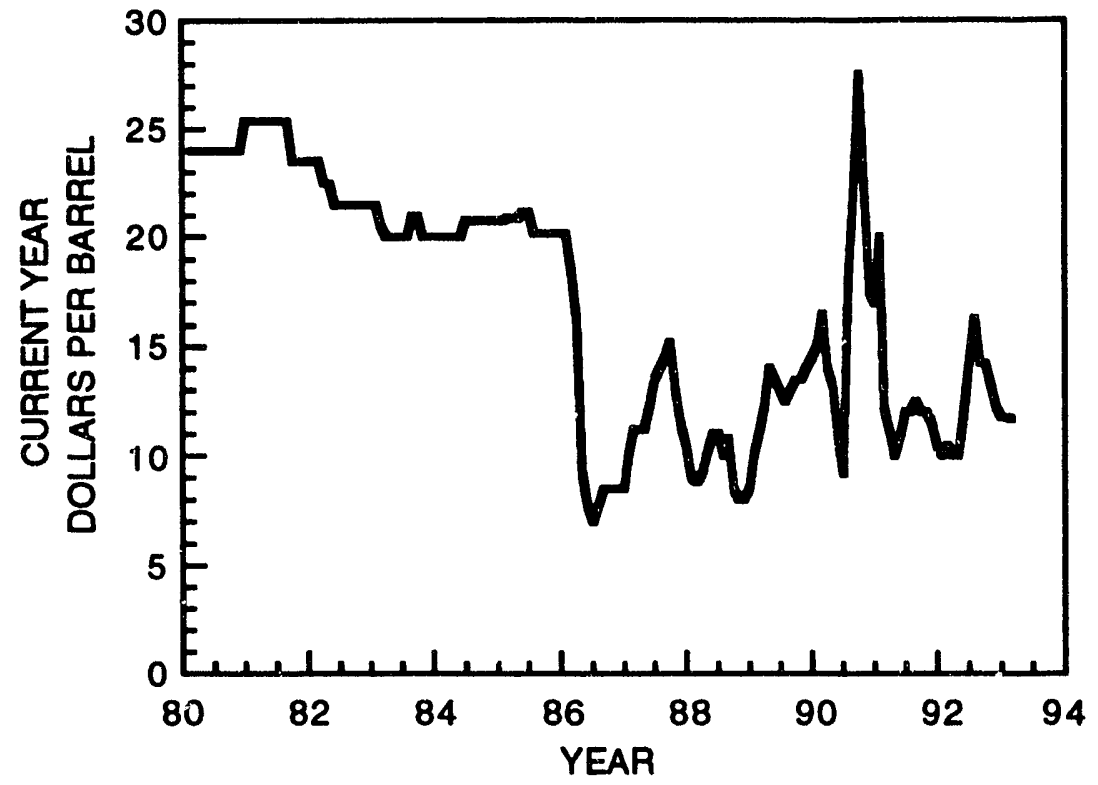

FIGURE 4. - Kern River, $13^{\circ}$ API posted price per barrel. (Maples, 1990, Oil \& Gas J. Weekly posted prices, 1993)

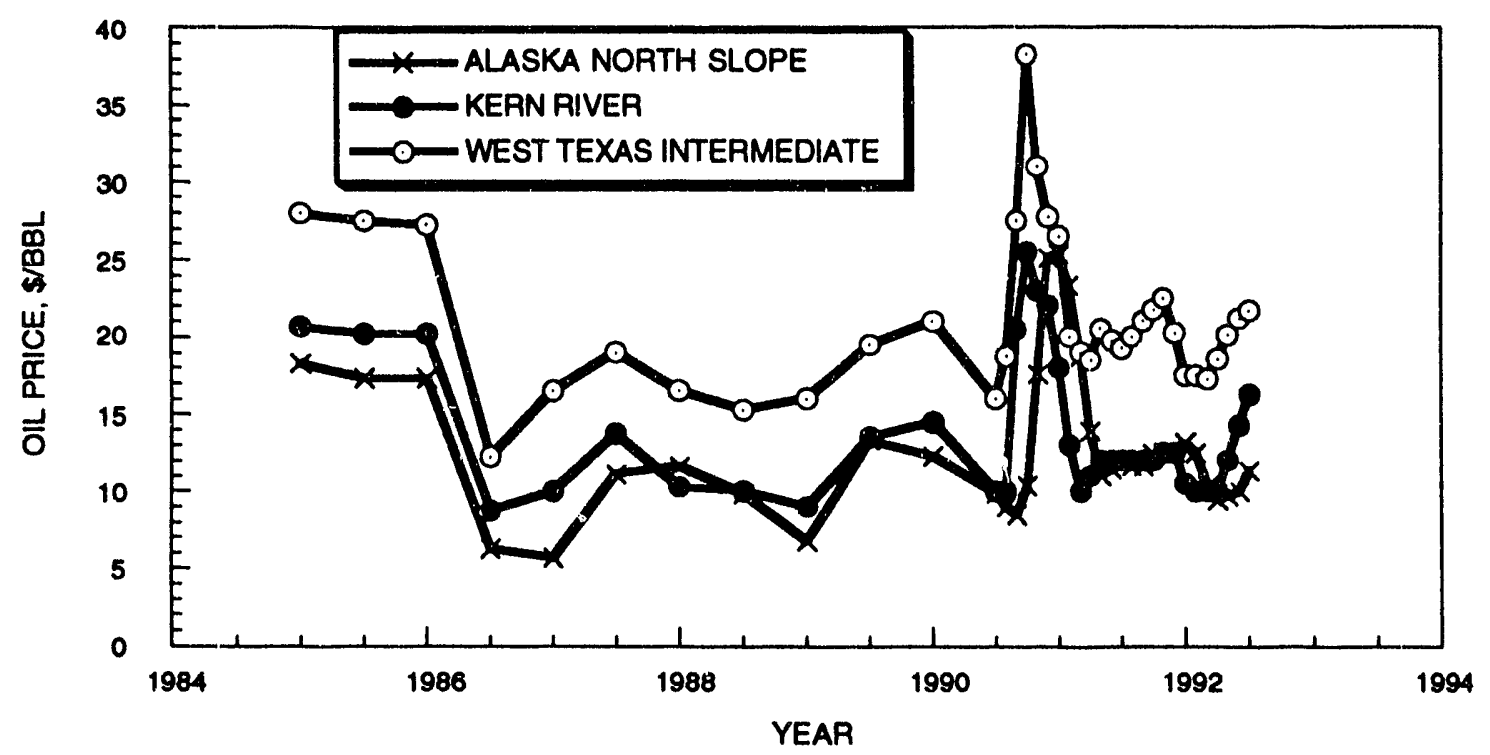

Prices quoted as point of origin.

FIGURE 5. - Oil price per barrel for representative U.S. crude oils. (Maples, 1990, Oil \& Gas J. Weekly posted oil prices) 
TABLE 2. - Average Annual Crude Oil Prices of the Past Decade (Maples, 1993)

\begin{tabular}{|c|c|c|c|}
\hline Year & $\begin{array}{c}\text { West } \\
\text { Texas } \\
\text { Intermediate, } \\
\$ / b b \mid\end{array}$ & $\begin{array}{l}\text { Kern } \\
\text { River, } \\
\text { \$/bbi }\end{array}$ & $\begin{array}{c}\text { Kern River / WTI } \\
\text { Ratio }\end{array}$ \\
\hline $\begin{array}{l}1983 \\
1984 \\
1985 \\
1986 \\
1987 \\
1988 \\
1989 \\
1990 \\
1991 \\
1992 \\
\text { Average of } \\
1983-1992\end{array}$ & $\begin{array}{l}30.33 \\
29.37 \\
28.01 \\
15.04 \\
19.17 \\
15.98 \\
19.69 \\
24.51 \\
20.16 \\
19.89\end{array}$ & $\begin{array}{c}20.14 \\
20.89 \\
20.18 \\
9.42 \\
13.34 \\
9.79 \\
12.77 \\
16.15 \\
12.14 \\
13.09\end{array}$ & $\begin{array}{l}0.66 \\
0.71 \\
0.72 \\
0.63 \\
0.70 \\
0.61 \\
0.65 \\
0.65 \\
0.60 \\
0.66 \\
\\
0.66\end{array}$ \\
\hline
\end{tabular}

Since thermal heavy oil production depends on maintaining long-term steam injection and constant cash flow, fluctuating oil prices-especially at low oil prices-make heavy oil production risky. For independent oil producers, operation dejends on being able to sell their oil either at the posted price or under a long-term contract which is usually tied to the posted price. If the independent producers (or in some cases, major heavy oil producers, who are producing in excess of what their downstream operations can handle) do not like the price, they have to be able to afford transportation to a market where there is a better price. Transportation parameters are more demanding and costly for heavy oil compared to light oil. Without added heat and/or in some cases viscosity reduction additives including light oil as diluent, heavy oil usually has higher viscosity than light oil which limits pipeline throughput and/or the ability to load and unload storage tanks, tankers, barges, trucks, and railcars. The refining/product margins on heavy oil are often low compared to those of light oil. With the rising demand for cleaner motor fuels with less aromatics, lower sulfur and lower nitrogen content, the oil price differentials for oil quality may increase. Unless oil production, transport, refining, and marketing (sales of gasoline) are provided within a vertically integrated company, it is generally much more difficult for heavy oil to compete effectively with light oil on a spot market basis.

\section{Projected Oil Production Levels, Locations, and Volumes for Future Heavy Oil}

The above review of factors related to heavy oil production and of past benchmark production forecasts, coupled with NIPER's analyses of heavy oil resource and producing areas, provided NIPER with tools and assumptions to develop two case scenarios by which increments of expanded heavy oil could be produced between the years 1990 and 2010. In the Case 1 "free market" scenario, which includes time frames and locations, three incremental production 
expansion levels by the year 2010 were developed: 930,000 BOPD (the 1991 NES target); 500,000 BOPD; and 300,000 BOPD. Each of these increments is over-and-above existing current production of 750,000 BOPD. In the Case 2 "managed market" scenario, production levels on a minimum, maximum and most probable production basis were developed, without time frames, but including locations. The following is a discussion of the assumptions and qualifications of the two production scenarios:

Case 1-The "free market" scenario is generally based on more realistic assumptions than the second Case. The scenario has two groups of assumptions. The first group (A) of assumptions for Case 1, assumptions 1-8, are considered to be more historically realistic than the second group. The second group (B), assumptions 9-10, includes those assumptions that were subjectively judged to be more speculative than other assumptions in Case 1 .

Case 2-The "managed market" scenario is based on assumptions that as a whole can be considered more unlikely, optimistic, speculative and less realistic than most of those given for Case 1. The Case 2 scenario is based on the assumption of government imposition of regulations causing imported crude oil and/or refined products to cost twice that of domestically produced oil and/or products. The Case 2 examination gives maximum consideration to producing those known heavy oil resources which are either seen and/or anticipated to be readily producible with current and likely advanced technology. Case 2 is designed to show what might happen under extremely supportive conditions. It provides perspective as to what might be physically attainable with "allout" encouragement and incentives. The purpose of Case 2 projections are to examine which heavy oil areas would be developed if significant changes in the U.S. petroleum industry occurred.

Each of the two scenarios (Case 1 and 2) are presented in the following format of discussion: (1) a listing of the assumptions, (2) a general discussion of the scenario and important observations, and (3) a discussion of the projected levels of heavy oil production by region.

The reader is cautioned, that these heavy oil projections should not be construed as forecasts. They are seen as plausible projections that might exist if conditions are as spelled out in the assumptions cited in the two cases. The reader should note that the projections and case assumptions are those of NIPER, and do not necessarily reflect any official position of DOE.

All of the production levels presented in the Case 1 scenario are seen as plausible, if not possible, with significant investment. The production levels given in the Case 2 scenario are seen as much less plausible.

NIPER's analyses of the Nation's heavy oil resource areas included analyses of their geologic setting and resource volume relative to existing or potential production and processing infrastructure; i.e., production facilities, pipelines serving the area, and local and/or regional heavy 
oil refining capacity or the lack thereof. They also included analyses of crude oil properties, reservoir geology and parameters such as depth, production technology and design, anticipated production problems, economics, and environmental considerations. These analyses were used to make projections as to volumes, locations, and time frames for potential development/production of additional heavy oil. 'Two hypothetical cases were considered. Case 1 is the more probable, and in an attractive economic environment, it is possible. The first case projections consider three production levels: 900,000; 500,000; and 300,000 BOPD. Case 2 is an extreme, hypothetical, political/economic condition dictated by a high import fee. However, Case 2 illustrates those geographic areas with heavy oil resources that are potentially good future heavy oil producing areas as compared to poor areas for future heavy oil development.

Attempts have been made to produce heavy oil from most of the geologic basins of the U.S. where it has been found during the past three decades. Nearly all of the thermal oil recovery projects produced oil (the production technology works), but the geologic environment in which the recovery process was operated governed the economic success. Heavy oil recovery projects implemented in unconsolidated or easily friable sandstone reservoirs are the most economically viable. NIPER has researched and written a series of reports on the domestic heavy oil resource. These reports cover the Midcontinent (Kansas, Missouri, Oklahoma), the Permian Basin (west Texas and eastern New Mexico), the Midwest and Appalachian Basins, California, and Alaska. Other reports either in progress or planned are on the Rocky Mountain States, including Wyoming, and the U. S. Gulf Coast (east and south Texas, Louisiana, Mississippi, and Arkansas).

Case 1 - "Free Market" Scenario: Heavy Oil Development Following Current Trends in the Economy, Politics, and the Oil Patch.

More realistic assumptions (Group A):

1. There is no government restriction or fees on importing crude oil. The U.S. petroleum industry operates in a free world market economy.

2. Oil prices will be significantly influenced by OPEC and follow the OPEC proposed price structure. However, for this study, acquisition costs for oil in current dollars are as follows:

\begin{tabular}{|c|c|c|c|c|c|}
\hline Year & $\begin{array}{c}\text { U. S. Average } \\
\text { Acquisition Cost }\end{array}$ & Spot WTI & Kern River & $\begin{array}{l}\text { Arabian } \\
\text { Heavy }\end{array}$ & $\begin{array}{l}\text { Arabian } \\
\text { Light }\end{array}$ \\
\hline 1990 & $\$ 22.35$ & $\$ 24.45$ & $\$ 16.15$ & $\$ 18.76$ & $\$ 20.80$ \\
\hline 2000 & $\$ 32.40$ & $\$ 35.00$ & $\$ 23.10$ & & \\
\hline 2005 & $\$ 41.75$ & $\$ 45.00$ & $\$ 29.70$ & & \\
\hline 2010 & $\$ 51.54$ & $\$ 55.00$ & $\$ 36.30$ & & \\
\hline
\end{tabular}

3. Heavy oil price is discounted $1 / 3$ of the WTI crude oil price for California asphaltic crude oils. Heavy oil is only penalized for gravity and sulfur for the rest of the lower 48 states.

4. There is no government incentive program to stimulate heavy oil or EOR production beyond current EOR tax credits.

5. The trends in production of heavy oil in the Los Angeles and Coastal Range Basins continue to follow the decline established over the past few years.

6. Environmental and economic restrictions continue to prevent the construction of a new grass roots refinery. 
7. Continued environmental pressure keeps the Los Angeles refineries from expanding, but it still allows them to operate within the Los Angeles Basin at their current processing level.

8. The EPA does not regulate oil field produced water as hazardous wastes. The petroleum industry continues to be environmentally conscious and meets current EPA and state requirements.

More speculative assumptions (Group B)

9. Nationalized oil companies or major international oil companies welcome domestic heavy oil as their own equivalent foreign heavy oil at U.S. refineries where they have controlling ownership.

10. Major changes in gasoline formulations beyond the 1990 Amendments to the Clean Air Act are not required to comply with future air quality regulations.

\section{General Discussion for Case 1}

Alaska is shown as having little heavy oil production in all of the projections. Since these projections are based only on the scarce information in the public domain, they should in no way be considered forecast. While major companies operating on the North Slope have been conducting in-house studies, and field pilots have been conducted, the results of these studies have not been made public (Conservation Commission of Alaska, 1991). A "back of the envelope" calculation of oil price factors based on posted prices illustrates the difficulty in producing heavy oil in Alaska. The January 1991 posted price for ANS was $\$ 9.50$. The approximate cost for transportation of $27^{\circ}$ API gravity ANS crude to Valdez, Alaska is $\$ 6.00 / \mathrm{bbl}$ and an additional $\$ 1.00$ to a refinery in California. The delivered cost (California) was approximately $\$ 16.50 / \mathrm{bbl}$. Transportation of ANS to Texas can add as much as another $\$ 2.50 / \mathrm{bbl}$. If heavy oil were thermally produced on the North Slope, it would most likely compete with California heavy oil selling at a posted price of around $\$ 10-12 / \mathrm{bbl}$. Since heavy oil is more difficult to transport than current ANS crude, it is anticipated that the transportation cost would be at least $\$ 7.00 / \mathrm{bbl}$ making the development of heavy oil with steam or in situ combustion uneconomic (Olsen, Taylor, Mahmood, 1992). The 3,000 BOPD of heavy oil that is being produced as primary production is not anticipated to significantly expand.

In making these projections, some decline in production was anticipated for the Coastal Range of California since most of the new heavy oil production is beyond the 3-mile offshore limit and is not counted in the Coastal Range production figures. This offshore heavy oil production could be substantial ( $>80,000$ BOPD) but is not anticipated to become significant due to long environmental permitting procedures and increasingly tight environmental regulations for offshore production. Despite waterflood expansion, the large Wilmington field will continue to mature. Therefore, Los Angeles Basin production was also projected to decline. Most of the projected new (additional) heavy oil will come from current heavy oil producing areas and Gulf Coast states unconsolidated sandstone reservoirs. 


\section{High Production Level}

The projections for the 900,000 BOPD increase in heavy oil "Table 3) by 2010 consider the lead times required to get production started by injecting significant heat into the ground using cyclic steam. This production level is double the current thermally produced heavy oil level, which required nearly thirty years to develop in California. This production target as envisioned would be a significant challenge of the order of a Manhattan or Man on the Moon project. The technology is available as well as the resource but the incentive for developing heavy oil at this level is not present under a free market scenario with unlimited oil imports.

\section{Mid-Level Production}

The projections for the 500,000 BOPD increase in heavy oil (Table 4) by 2010 consider the lead times required to get production started by injecting some heat into the ground using cyclic steam. This volume is equivalent to the volume of current U.S. thermally produced heavy oil (460,691 BOPD, Moritis, 1992). This was a consideration for most areas other than Wyoming which has many deep, warm heavy oil reservoirs that will probably not require the addition of heat for production. Most of the expansion would be anticipated after the year 2000 when Alaskan North Slope oil production has significantly declined. For production above 300,000 BOPD, a significant economic incentive would have to be implemented. Most of the production wculd come late in the time period because of the time required to bring a project on line; i.e., financing, engineering, permitting, development of the field, start cyclic steam injection, and construction of the necessary pipelines and refinery capacity.

TABLE 3. - Projected Heavy Oil Production Levels and Time Frames for an Additional 900,000 BOPD, Case 1

\begin{tabular}{|c|c|c|c|c|c|}
\hline \multirow[b]{2}{*}{ PADD } & \multirow[b]{2}{*}{ General location } & \multirow[b]{2}{*}{$\begin{array}{r}\text { BOPD } \\
1995 \\
\end{array}$} & \multicolumn{3}{|c|}{ Additional crude oil } \\
\hline & & & $\begin{array}{l}\text { BOPD } \\
2000 \\
\end{array}$ & $\begin{array}{r}\text { BOPD } \\
2005 \\
\end{array}$ & $\begin{array}{l}\text { BOPD } \\
2010 \\
\end{array}$ \\
\hline 1 & Entire PADD 1 & 0 & 0 & 0 & 0 \\
\hline 2 & Midcontinent (KS, MO, OK) & 1,000 & 2,000 & 3,000 & 5,000 \\
\hline 2 & Remainder of PADD 2 & 0 & 100 & 500 & $<1,000$ \\
\hline 3 & Permian Basin & 1.000 & 1,000 & 2,500 & $<5,000$ \\
\hline 3 & East Texas & 2,000 & 10,000 & 20,000 & 80,000 \\
\hline 3 & SE. Arkansas \& N. Louisiana & 2,000 & 15,000 & 50,000 & 130,000 \\
\hline 3 & South Texas Basin & 1,000 & 10,000 & 50,000 & 130,000 \\
\hline 3 & Texas Gulf Coast Salt Basin & 5,000 & 10,000 & 50,000 & 130,000 \\
\hline 3 & Louisiana Gulf Coast Salt Basin & 1,000 & 10,000 & 25,000 & 75,000 \\
\hline 3 & Mississippi Interior Salt Basin & 0 & 500 & 1,000 & $<5,000$ \\
\hline 4 & Wyoming, Montana & 1,000 & 10,000 & 20,000 & $>40,000$ \\
\hline 5 & San Joaquin Valley & 40,000 & 40,000 & 90,000 & 200,000 \\
\hline 5 & Los Angeles Basin & $-5,000$ & $-10,000$ & $-2,000$ & $-1,000$ \\
\hline 5 & Coastal Range California & 30,000 & 50,000 & 75,000 & 100,000 \\
\hline 5 & North Slope, Alaska & 10.000 & 11.000 & 15,000 & 30,000 \\
\hline \multirow{2}{*}{\multicolumn{2}{|c|}{ TOTAL }} & 91,000 & 158.500 & 400,000 & 930,000 \\
\hline & & 90,000 & 150,000 & 400,000 & 900,000 \\
\hline
\end{tabular}




\section{TABLE 4. - Projected Heavy Oil Production Levels and Time Frames for an Additional 500,000 BOPD, Case 1}

\begin{tabular}{|c|c|c|c|c|c|}
\hline \multirow[b]{2}{*}{ PADD } & \multirow[b]{2}{*}{ General location } & \multirow[b]{2}{*}{$\begin{array}{l}\text { BOPD } \\
1995 \\
\end{array}$} & \multicolumn{3}{|c|}{ Additional crude ell } \\
\hline & & & $\begin{array}{l}\text { BOPD } \\
2000 \\
\end{array}$ & $\begin{array}{r}\text { BOPD } \\
2005 \\
\end{array}$ & $\begin{array}{r}\text { BOPD } \\
2010 \\
\end{array}$ \\
\hline 1 & Entire PADD 1 & 0 & 0 & 0 & 0 \\
\hline 2 & Midcontinent (KS, MO, OK) & 1,000 & 2,000 & 3,000 & 5,000 \\
\hline 2 & Remainder of PADD 2 & 0 & 100 & 500 & $<1,000$ \\
\hline 3 & Permian Basin & 1,000 & 1,000 & 2,500 & $<5,000$ \\
\hline 3 & East Texas & 2,000 & 10,000 & 20,000 & $>25,000$ \\
\hline 3 & SE. Arkansas \& N. Louisiana & 2,000 & 15,000 & 50,000 & 100,000 \\
\hline 3 & South Texas Basin & 1,000 & 10,000 & 50,000 & 100,000 \\
\hline 3 & Texas Gulf Coast Salt Basin & 5,000 & 10,000 & 50,000 & 100,000 \\
\hline 3 & Louisiana Gulf Coast Salt Basin & 1,000 & 10,000 & 25,000 & 50,000 \\
\hline 3 & Mississippi Interior Salt Basin & 0 & 500 & 1,000 & $<5,000$ \\
\hline 4 & Wyoming, Montana & 1,000 & 10,000 & 20,000 & $>25,000$ \\
\hline 5 & San Joaquin Valley & 40,000 & 40,000 & 90,000 & 150,000 \\
\hline 5 & Los Angeles Basin & $-5,000$ & $-10,000$ & $-15,000$ & $>-20,000$ \\
\hline 5 & Coastal Range California & 30,000 & 50,000 & 50,000 & 70,000 \\
\hline 5 & North Slope, Alaska & 10.000 & 11.000 & 5.000 & 5.000 \\
\hline \multicolumn{2}{|c|}{ TOTAL } & 91,000 & 158,500 & 317,000 & 561,000 \\
\hline \multicolumn{2}{|c|}{ TOTAL APPROXIMATE VALUES } & 90,000 & 150,000 & 300,000 & 500,000 \\
\hline
\end{tabular}

\section{Low Production Level}

The estimated additional heavy oil projection of 300,000 BOPD (Table 5) seems achievable based on the known heavy oil resource, although additional investment in heavy oil refining and transport capability would be required. The highest projections for increased heavy oil production by 1995 are within California, 65,000 BOPD. This is the only area that has the oil resources and infrasiructure to bring on line this volume of oil by 1995 . However, limitation of California refining capacity may severely limit this volume as shown by the performance of the industry over the past few years. Since 1989, several small refineries have shutdown, Chevron opted out of building a large coker, environmental regulations have become stiffer, environmental permit procedures have become longer, and fuel quality standards have risen substantially with the passage of CARB, California Air Resources Board, emission regulations. However, Alaskan North Slope light oil production is anticipated to decline rapidly based on the current decline curve of Prudhoe Bay field (Thomas et al., 1991). The production increase of Alaskan heavy oil will not contribute substantially to arresting the projected ANS production decline. Other areas have oil production potential but startup of oil production takes investment in infrastructure and heat, and this requires time. 
TABLE 5. - Projected Heavy Oil Production Levels and Time Frames for an Additional 300,000 BOPD, Case 1

\begin{tabular}{|c|c|c|c|c|c|}
\hline \multirow[b]{2}{*}{ PADD } & \multirow[b]{2}{*}{ General location } & \multirow[b]{2}{*}{$\begin{array}{l}\text { BOPD } \\
1995 \\
\end{array}$} & \multicolumn{3}{|c|}{ Additional crude oil } \\
\hline & & & $\begin{array}{l}\text { BOPD } \\
2000 \\
\end{array}$ & $\begin{array}{r}\text { BOPD } \\
2005 \\
\end{array}$ & $\begin{array}{r}\text { BOPD } \\
2010 \\
\end{array}$ \\
\hline 1 & Entire PADD 1 & 0 & 0 & 0 & 0 \\
\hline 2 & Midcontinent (KS, MO, OK) & 1,000 & 2,000 & 3,000 & 5,000 \\
\hline 2 & Remainder of PADD 2 & 0 & 0 & 0 & 0 \\
\hline 3 & Permian Basin & 0 & 0 & 1,000 & $<2,000$ \\
\hline 3 & East Texas & 2,000 & 5,000 & 10,000 & $>20,000$ \\
\hline 3 & SE. Arkansas \& N. Louisiana & 2,000 & 15,000 & 25,000 & 50,000 \\
\hline 3 & South Texas Basin & 1,000 & 10,000 & 25,000 & 40,000 \\
\hline 3 & Texas Gulf Coast Salt Basin & 5,000 & 10,000 & 25,000 & 40,000 \\
\hline 3 & Louisiana Gulf Coast Salt Basin & 1,000 & 5,000 & 10,000 & 25,000 \\
\hline 3 & Mississippi Interior Salt Basin & 0 & 0 & 0 & 0 \\
\hline 4 & Wyoming, Montana & 1,000 & 5,000 & 8,000 & 8,000 \\
\hline 5 & San Joaquin Valley & 40,000 & 40,000 & 40,000 & 65,000 \\
\hline 5 & Los Angeles Basin & $-5,000$ & $-10,000$ & $-15,000$ & $>-20,000$ \\
\hline 5 & Coastal Range California & 30,000 & 50,000 & 50,000 & 50,000 \\
\hline 5 & North Slope, Alaska & 10.000 & 10.000 & 11.000 & $>15.000$ \\
\hline \multicolumn{2}{|c|}{ TOTAL } & 88,000 & $\overline{142,500}$ & 193,000 & 300,000 \\
\hline \multicolumn{2}{|c|}{ TOTAL APPROXIMATE VALUES } & 90,000 & 140,000 & 190,000 & 300,000 \\
\hline
\end{tabular}

\section{Case 1 Regional Effects}

The estimates for the locations of future heavy oil production, volumes of oil, and possible time frames when heavy oil may become available were developed based on knowledge of the heavy oil resources, known constraints to production, transportation, refining, and anticipated trends in the heavy oil market. Using the assumed increases in production levels $(900,000$; 500,000 ; or 300,000 BOPD) as incremental production goals, the productivity in each area was estimated based on past performance and the perception of potential future performance. Ratios of production were developed and scaled heuristically to fulfill the projected production target. This was done by evaluating: (a) the known oil and reservoir characteristics in an area, (b) the available transportation networks and refining capacities, and (c) the known or previous production capacities of the various areas. Potential production capacities, in the case of areas with little current or historical heavy oil production, were derived by considering only the first two of these factors. The following descriptions of the resource and production potential are the basis for Tables 3 through 5. Maps of the U.S. heavy oil reservoir locations are shown in Figs 1 and 6.

PADD 1 is a non-heavy oil region and contains only a few reservoirs with heavy oil. They are in tight consolidated sandstones. Thermal enhanced oil recovery (TEOR) may help to significantly improve the productivity of light oils with low pour point found in shallow, pressuredepleted fields in the Appalachian Basin but the volume of this resource has not been defined. The economics of this may be attractive because the oil produced refines to superior lubricating oil and commands a premium price. Reservoirs are primarily consolidated sandstones and carbonates. 


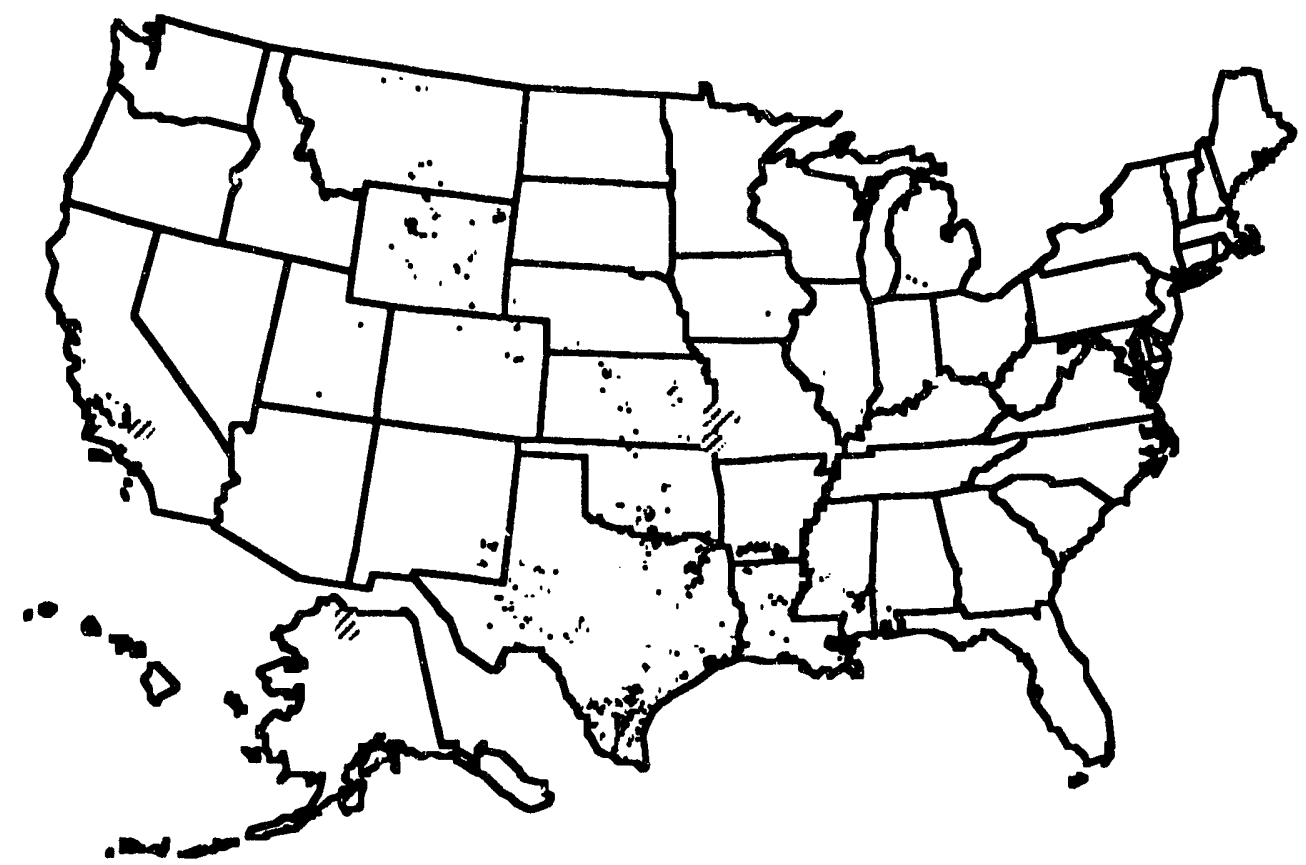

FIGURE 6. - Map of the United States showing heavy oil field locations.

PADD 2 Midcontinent (Kansas, Missouri, Oklahoma) heavy oil reservoirs are in consolidated formations, with the exception of the unconsolidated sands of south-central Oklahoma. Small volumes of oil are producible by TEOR, but no large increase in heavy oil production is anticipated, except perhaps in south-central Oklahoma. The remainder of PADD 2 contains only three heavy oil reservoirs in Nebraska, two in Illinois, and four in Michigan. Each of these reservoirs is in consolidated formations, and the oil resource is small.

PADD 3 has five regions with heavy oil prospects. Two of these, the Permian Basin and the Mississippi Interior Salt Basin, are not heavy oil producing basins, although both have some heavy oil. The heavy oil production from the Permian Basin, in eastern New Mexico and the west Texas Railroad Commission (RRC) districts 8, 8A, and parts of 7B and 7C, is small due to the nature of the resource being found in very tightly consolidated carbonate and sandstone reservoirs.

East Texas has several large heavy oil reservoirs capable of being thermally produced. Currently, however, some operators producing heavy oil in the area are having difficulty selling their oil. Exxon is looking at steaming parts of the Hawkins Field, which if economical could easily add significant heavy oil production potential. Since we have not analyzed all the East Texas reservoirs in detail, the estimated increase in heavy oil may be conservative compared to their potential. If the technology currently being initiated to test heavy oil production from Hawkins is technically and economically successful, these estimates will be low.

Southern Arkansas and northern Louisiana have broadly distributed Nacatoch, Tokio, and other unconsolidated or easily friable sandstones containing significant volumes of heavy oil. This 
region's production operations are mostly conducted by small independent oil companies. Some long-term successful thermal oil production operations have been conducted in the area, but applications have not been widespread. This area has significant production potential and was estimated in excess of 100,000 BOPD under Case 1 assumptions.

Tertiary and Cretaceous sand reservoirs of South Texas, the Texas Gulf Coast Salt Basin, and the Louisiana Gulf Coast Salt Basin are principally shallow, unconsolidated or friable sandstones. Many of these reservoirs are the closest in character to typical California heavy oil reservoirs of any region in the U.S. Large volumes of heavy oil are expected to become available from unconsolidated sandstone reservoirs of Cretaceous Age within Texas' two arches. The first arch covers Texas Railroad Commission (RRC) districts 1, 5, 6, and parts of " $\mathrm{C}$ and 7B. This arch extends to southwest Arkansas and northwest Louisiana (Nacatoch sands). The second arch is along RRC districts 2, 3 and 4 and extends across the Gulf to Louisiana and southern Mississippi. Along with the Nacatoch, these areas are seen as key heavy oil production growth areas of the next few decades.

Many of these heavy oil reservoirs in the Gulf Coast States occur in the same fields as light oil reservoirs that were developed decades earlier. Texas heavy oil reservoirs in many cases have been overlooked because they occur in fields that have light oil production. Production from most of these heavy oil reservoirs has been stripper production, although a few operators have used cyclic steam on a very limited basis. These reservoirs have heavy oil that is usually $>15^{\circ} \mathrm{API}$, $<20^{\circ} \mathrm{API}$, and naphthenic or paraffinic rather than the asphaltic $<15^{\circ}$ API gravity heavy oil typical of California. Therefore, this oil commands a higher price compared to California heavy crudes. Heavy oil recovery using geothermally produced hot water may have great potential for many of the Texas Gulf Coast Salt Basin and Louisiana Gulf Coast Salt Basin heavy oil reservoirs (Geothermal hot water, $500^{\circ} \mathrm{F}$ ) is present in close proximity to several heavy oil reservoirs. The Gulf Coast has the largest heavy oil refining capability of any area outside of California. For all these reasons, this region was estimated to have the highest heavy oil production potential, in excess of 300,000 BOPD, and it has the potential to become the second major heavy oil producing region of the U.S.

PADD 3, the Gulf Coast, has refinery capacity in excess of 6.6 million barrels per calendar day (BCD), whereas PADD 5, the West Coast. has refinery capacity of 3 million BCD, with California refining 2.0 million BCD (Oil \& Gas J., 1993). The combination of a significant heavy oil resource with the significant refining capacity of the Gulf Coast should be an incentive to concentrate efforts to define more accurately the heavy oil areas in PADD 3 in order to determine the potential of heavy oil development in this area.

In PADD 4, northern Wyoming (Powder River and the Big Horn Basins) and southern Montana, has a significant heavy oil resource, but most of their reservoirs are deep $(>4,000 \mathrm{ft})$, 
and the sediments are consolidated. Many of these reservoirs are drilled on wide spacing and are waterfloodable because of the low viscosity of the oil and the high gas/oil ratio (GOR) within the reservoirs. When separated from the gas or cooled, the heavy oil behaves like heavy oil of the $18^{\circ}$ to $20^{\circ}$ API range. Several light and heavy oil reservoirs exist in this area, but the region has very limited refining capacity, although upgrading capacity (coker) is being expanded to accommodate growth of Canadian imports. The Rocky Mountain refining industry, PADD 4, refines the lightest, lowest sulfur stream of any region. In the last decade, PADD 4 has seen an increase (10\% of the feed stream in the early 1980 s to $15 \%$ in 1990) in imported (Canadian) oil refined in the PADD. The 18,0C0 to 20,000 BOPD of heavy oil currently being produced is blended with light sweet crude produced in surrounding fields. Because of a large number of reservoirs, a conservatively estimated increase of $>25,000$ BOPD could become available if production economics were to improve. The area has the best potential for nonthermal production of heavy oil.

In PADD 5, Alaskan North Slope (ANS) oil imported into Calitornia, combined with California state production, gives California refiners an ample supply of oil which acts to drive down the price of heavy oil and increase the margin between heavy and light oil. The San Joaquin Valley of California is currently the largest heavy oil producing region of the U.S. It has great capacity for production because of its large heavy oil resource and existing production infrastructure. However, California refineries, as presently operating, have all the asphaltic heavy oil they can economically process. The alternatives are to ship the heavy oil to the Gulf Coast or not produce the oil. When transportation costs to the Gulf Coast and production costs are combined, the value frequently exceeds the price that a Gulf Coast refiner will pay for Kern River heavy oil. Imported heavy crude from Venezuela and Mexico is economically more attractive than California heavy oil for the Gulf Coast refiner.

The California heavy oil market is saturated at present, but as ANS oil production declines, California will rely on more San Joaquin Valley and Coastal Range (mostly offshore) crude or increases in light oil imports to make up the deficit. The San Joaquin Valley, because of its rich resource base, could develop an additional 200,000 BOPD as ANS oil production and deliveries dip, especially if investments in overcoming environmental constraints continue. When California environmental constraints on production and refining are considered, expansion is still possible with the increased use of gas-fired steam generators for TEOR and better emission control equipment. One inhibiting factor to the increase of heavy oil production in California will be the import of larger amounts of South American medium and light crudes and Pacific Rim light oil to replace the light ANS crude; i.e.-"quality for quality" replacement. If heavy oil prices remain low or if there is no incentive to ship heavy oil outside the current refining region to overcome some of the effects of higher transportation costs and unlimited imports of the South American and Pacific 
Rim light and medium crude oil imports into the region, the prospects for significant additional heavy oil production development in California are not high.

The Los Angeles Basin has experienced a steady decline in oil production since the late 1960s. Population increases and environmental constraints on production and refining are limiting oil production. The area is one of the largest marketing areas, but cleaner fuel restrictions limit the economics of heavy oil processing because heavy oil dies not yield clean products as economically as light paraffinic crudes. Despite waterflood expansion, the large Wilmington area will continue to mature. Consequently, the Los Angeles Basin is expected to lose heavy oil production capacity and will have to struggle and invest in refining capacity upgrades to meet environmental and product quality restrictions to maintain current refining capacity.

The Coastal Range of California has significant heavy oil both onshore and in the Santa Barbara Channel. Environmental concerns and constraints have delayed expansion of several projects in oil production, transportation, and refining capabilities that could boost all of California's production. With some incessions on environmental constraints (such as tanker transport of heavy oil from offshore platforms to Los Angeles, rather than by pipeline to Bakersfield and then to San Francisco and then by tanker to Los Angeles), one major oil company suggests that an additional 70,000 BOPD of heavy oil production could easily be produced. Most companies are now leery of investments in this area because of the high liability and track record showing long delays in trying to get a project started. Therefore, additional heavy oil, beyond that currently behind pipe, may never be produced in the Coastal Range or in offshore fields despite the large heavy oil resource.

Based on the public information available, not enough is known to adequately assess the heavy oil resource in Alaska. The installation of two massive gas recycling systems on the North Slope have postponed, only temporarily, the oil production decline (Thomas et al., 1991; Olsen, Taylor and Mahmood, 1992). The constraints on heavy oil production with steam in the harsh environment of the North Slope and the high cost of transportation will probably prevent most of that heavy oil resource from being produced for decades, although Conoco is producing $>3,000$ BOPD (December 1991, Alaska Division of Natural Resources, 1992) from Milne Point Field with anticipated expansion. Conoco is considering the use of hydrocarbon soluents to miscible flood the West Sak reservoir at Milne Point. New wells produced 300 BOPD, and an estimated 200 wells may be drilled. However, a year later (December, 1992) heavy oil production was 3162 BOPD but the anticipated rate of decline is not publicly available (Alaska Oil and Gas, 1993). Use of downhole steam generators, insulated tubing, the supply of light oil for diluent for pipelining heavy oil, and additional heating capacity of the pipeline are only some of the major hurdles that operators are analyzing in feasibility studies for producing heavy oil from the North Slope. Many of the smaller light oil reservoirs that have been discovered are not commercial at today's oil price. 
Undetermined resources of both light and heavy oil remain to be discovered and developed on the North Slope and interior Alaskan Basins.

With current government policy, there does not appear to be enough economic incentive to develop appreciable amounts of Alaskan or other domestic heavy oil resources. Investments in other businesses or in petroleum production in other areas of the world look more attractive to many companies. Therefore, the United States will import large volumes of Venezuelan and Mexican heavy oil to the Gulf Coast long before major heavy oil production is developed in Alaska. Gulf Coast heavy oil will be developed before Alaskan North Slope heavy oil. It is anticipated that light and medium gravity oil reservoirs will be developed on State of Alaska lands before significant heavy oil production will occur on federal lands on the North Slope of Alaska.

\section{Case 2 - "Managed Market" Scenario: Heavy Oil Development Following Legislation that Encourages Domestic Production. A Major Political and Economic Change Affecting the Uil Patch.}

The second case is an "extremely supportive/protective" hypothetical political/economic condition where the U.S. energy market is strongly managed. This very unlikely scenario, based on known heavy oil resources and on regional pipeline and refining infrastructure, highlights those geographic areas with good future heavy oil production potential compared to those with poor future heavy oil production potential. Case 2 estimates indicate how much and where additional heavy oil will come on-line in the next two decades. These estimates are on a minimum, maximum, and most probable production basis. Since the U.S. heavy oil industry competes in a dynamic and competitive world oil market, these projections should be viewed with caution.

Assumptions used:

1. EPA or state environmental restrictions do not limit operations.

2. Domestic oil price is as predicted in assumptions in Case 1, but imported oil and/or refined products are twice the price of domestic crude oil and/or refined products due to government restrictions.

3. Major areas previously off limits due to environmental or other restrictions are opened for exploration and development including offshore and Alaska.

4. Alaska will initiate major development of heavy oil with a reserve of $>10$ billion bbl on the North Slope and light oil is allocated for diluent to meet pipeline requirements without significant transportation penalty added to each barrel pumped south.

5. The oil and gas industry applies good stewardship under current environmental regulations.

\section{General Discussion for Case 2}

Of the assumptions in Case 2, the pricing structure in assumption 2 has overwhelming consequences. In essence, this is a major change in government pelicy and energy price structure, but it could generate significant capital investment in domestic oil pr iduction (light and heavy) and domestic oil processing (transportation, refining, etc.) by the U.S. petroleum industry and other investors. In addition, it could sharply increase the number of jobs in the energy sector and reduce the U.S. trade imbalance since the cost of imported crude oil and refined product are significant 
part of the trade deficit. This is not without significant cost to the consumer and would lead to more efficient use of energy. Assumption 2 is that the U.S. Government imposes restrictions such that the refiner has to pay twice as much for foreign oil as for domestic, regardless of oil quality. The assumption applies to both imported crude oil and imported refined products. If this assumption is applied only to in:ported crude oil, then major investment and construction of foreign refining capacity would be undertaken, and all imports would be refined products. This would result in the U.S. refining industry shrinking, and only those very large refineries with economies of scale and dependable, readily available domestic resources would survive. Major oil companies would accelerate their exodus from the U.S., and the U.S. would become more dependent upon foreign refiners as well as foreign crude oil. The assumptions in Case 2 are not that far removed from the "Energy Independence" concept proposed during the Carter administration.

Since assumption 2 applies to both imported crude oil and refined product imports, gradual phase in is necessary. Otherwise sharply reduced imports, as might quickly occur at the beginning, would cause a major energy shortage in the U.S. This would result in skyrocketing domestic crude and refined product prices anticipated because Americans remain tied to having one person to a car rather than using mass transportation or having thermostats set to conserve energy. If implemented over a 10-year period, this assumption would dramatically alter the behavior of the U.S. public and the structure of world oil production and refining markets.

Lead times on construction of refineries are often 10 years before the first barrel of product is produced and ways around the long permitting procedures for all types of facilities would have to be implemented. Accelerated natural gas production and consumption would be anticipated, as well as development of alternative energy sources. Conservation and better efficiency in energy use would be undertaken. Enhanced oil recovery would boom, and all U.S. stripper wells would be pumped. It would be difficult to keep the domestic oil price at or below $\$ 28 / \mathrm{bbl}$ by the year 2000 and $\$ 35 / \mathrm{bbl}$ by 2010 (in constant dollars).

After estimating the potential heavy oil production under the second set of assumptions, the allocations in Table 6 reflect some interesting mobilization requirements. Heavy oil resources and locations of current refining complexes would have to match and be tied together with heated pipelines. Major heated pipelines would be needed in California, from South and East Texas to current refineries in the Midwest and the Gulf Coast and from Wyoming to current refineries in the Midwest. A second Alaskan pipeline may also be required. Several hydrocrackers, hydrotreaters, and cokers would have to be constructed to accommodate this increase in charge of heavy crude. California and Texas would become larger crude oil and refined product exporters (to other states) than they are at present. Alaska would produce additional heavy oil, but the high cost of production and delivery to the West Coast or Gulf Coast fur refining would encourage faster 
development of a second major heavy oil industry operating in the unconsolidated Tertiary Age reservoirs of Texas, Arkansas, Louisiana, and Mississippi because of lower oil production and transportation costs.

Under Case 2 assumptions, with producible light oil still to be found though at increasing cost as the resource becomes more and more marginal, the major oil patch emphasis would continue to be light crude oil product.un. Methods such as infill drilling, horizontal drilling, and EOR for light oil production would receive the highest industry priority. The reason for this priority is the easier production, transportation and the higher margins achievable from refining light crude. The increase in heavy oil production would come from expansion in current fields and known heavy oil fields where the rate of return on a project under Case 1 might be unacceptable for a major project involving thermal EOR (in situ combustion, cyclic steam, or steam drive), but which are favorable in Case 2 because of the higher oil demand and price.

\section{Case 2 Regional Effects}

The following descriptions of the resource and production potential, including reservoir geology and downstream factors such as pipeline and refining capacity to process heavy oil, are the basis for Table 6. Both heavy and light oil would be developed, and major investment would occur in the United States. These estimations are less firm, and only the trends are of real interest as they highlight good heavy oil producing areas and areas that will not be developed even under extreme pressure to produce oil.

\section{TABLE 6. - Projected Heavy Oil Production Under the Second Set of Assumptions, Case 2.}

\begin{tabular}{|c|c|c|c|c|c|}
\hline \multirow[b]{2}{*}{ PADD } & \multirow[b]{2}{*}{ General location } & \multirow[b]{2}{*}{ Specific location } & \multicolumn{3}{|c|}{ Additional crude oil } \\
\hline & & & $\underset{\text { BOPD }}{\text { Minimum }}$ & $\underset{\text { BOPD }}{\operatorname{Maximum}}$ & $\begin{array}{c}\text { Estimated } \\
\text { BOPD }\end{array}$ \\
\hline 1 & Entire PADD 1 & & 0 & 0 & 0 \\
\hline 2 & Midoontinent (KS, MO, OK) & & 2,000 & 25,000 & $<10,000$ \\
\hline 2 & Remainder of PADD 2 & & 1,000 & 10,000 & 5,000 \\
\hline 3 & Permian Basin & & 1,000 & 20,000 & $<20,000$ \\
\hline 3 & East Texas & Slocum, Camp Hill, Hawkins & 100,000 & 200,000 & $>150,000$ \\
\hline 3 & S. Arkansas \& N. Louisiana & Nacatoch & 100,000 & 500,000 & $>250,000$ \\
\hline 3 & South - Central Texas & Cretaceous unconsolidated sands & 100,000 & 500,000 & $>300,000$ \\
\hline 3 & Texas Gulf Coast Salt Basin & & 100,000 & 500,000 & $>200,000$ \\
\hline 3 & Louisiana Gulf Coast Salt Basin & & 100,000 & 500,000 & $>200,000$ \\
\hline 3 & Mississippi Interior Salt Basin & & 1,000 & 100,000 & 50,000 \\
\hline 4 & Northern Wyoming & & 5,000 & 200,000 & 100,000 \\
\hline 5 & San Joaquin Valley & Bakersfield & 250,000 & $1,000,000$ & $>400,000$ \\
\hline 5 & Los Angeles Basin & & 5,000 & 200,000 & $>100,000$ \\
\hline 5 & Coastal Region, California & & 100,000 & 400,000 & $>300,000$ \\
\hline \multirow[t]{2}{*}{5} & North Slope, Alaska & & 10.000 & 100.000 & $>50.000$ \\
\hline & $\begin{array}{l}\text { TOTAL } \\
\text { APPROXIMATE TOTALS }\end{array}$ & & $\begin{array}{l}875,000 \\
875,000\end{array}$ & $\begin{array}{l}4,255,000> \\
4,250,000>\end{array}$ & $\begin{array}{l}2,135,000 \\
2,000,000\end{array}$ \\
\hline
\end{tabular}


PADD 1 has no heavy oil resource. Significant thermal EOR would help production of low pour point, light crude oils in many of the old Appalachian Basin oil fields.

In PADD 2, Midcontinent (Kansas, Missouri, Oklahoma) oil producers would develop TEOR in some of the shallow, consolidated sandstones of western Missouri and eastern Kansas. Steam (cyclic flood) implemented with good geologic control will produce heavy oil, but not in significant volumes because of adverse environmental impact. The highest oil production could be expected from the unconsolidated sands of south-central Oklahoma. The remainder of PADD 2 has little heavy oil resource, and production would be minimal.

In PADD 3, the Permian Basin would be an extremely active light oil producing area. Development of heavy oil reservoirs within the area would have to compete for manpower, supplies, and pipeline capacity. Therefore, the limited heavy oil resources would not be developed as fast or to their potential due to local competition for resources.

East Texas, Southwest Arkansas, and Northern Louisiana would be major areas producing both light and heavy oil. Substantial heavy oil would be produced by thermal methods (cyclic steam, steamdrive and in situ combustion). The refineries and the aging pipeline system in the area would need to be greatly expanded. A heated pipeline to Gulf Coast and possibly Midwest refineries would be required to transport oil to refineries which currently refine predominantly imported crude oii. This area would become the third largest heavy oil producing area in the United States.

South-central Texas and the Texas and Louisiana Coastal Salt basins would be the second largest heavy oil producing area outside of California. The Tertiary age, predominantly friable or unconsolidated sandstone, reservoirs would be developed by cyclic steam and steamdrive and to a much lesser extent through in situ combustion. Oil production would be carried via pipelines with diluent to Gulf Coast refineries. Because of the widespread nature of the reservoirs, the production would not be as confined as California production.

In PADD 4, Northern Wyoming and Southern Montana would experience an intensive infill drilling program, and more heavy oil reservoirs would be waterflooded. Because of limited refining capacity to process heavy oil and the small volume regional fuel oil market, the heavy oil resource would not be developed to its maximum extent unless either a heated pipeline or pipeline with significant light diluent was constructed from Wyoming to refineries in the Midwest. Some refinery capacity would be released as imports of Canadian oil declined.

In PADD 5, Southern California would become even more of a major oil producer and refiner. The environmental limitations which retarded growth in the first scenario would need to be relaxed in the interest of keeping the Nation's oil production and refining industry supplying the national demand for liquid fossil fuel. Major expansion of thermal heavy oil production would be emphasized because most of the light oil reservoirs are well along on their decline curve. Alaskan 
oil would be brought into California at much higher rates, even if a major pipeline were constructed from Seattle to the Midwest. The All American pipeline (300,000 BOPD capacity) would finally use its heating capacity and move substantial California and ANS oil to Gulf Coast refineries.

Alaska would become the major oil producing state, and hopefully another giant or super giant oil field would be found on the North Slope. Light and medium gravity oil fields that were previously uneconomic would be developed. A second pipeline would be required. A trans Canadian line from the North Slope to the lower 48 States, as proposed in the 1970s, would be considered if the Canadians could tax the contents and make up for some of the thousands of BOPD lost in export sales because of the restrictions of this scenario. Alaskan heavy oil would be developed, but priority would go to medium and light oil production.

\section{REFINERY AND PRODUCTION CONSIDERATIONS}

The reader is reminded that the oil production increases set forth in this report are not forecasts but logical projections of what could be produced. The likelihood is another matter. Production cannot occur unless the refinery mix can accommodate the additional domestic heavy oil. The following discussion and figures are provided to provide additional production and refining perspectives necessary in evaluating the potential of the heavy oil projections given in the Case 1 and Case 2 scenarios. This perspective can best be seen through examination of select crude oil feedstock characteristics and refinery trends followed by observations of trends in California production and market factors.

\section{Refinery Feedstock Character}

In November 1991, the U.S. was producing 7,331,000 BOPD but by January 1993, production had declined to 6,980,000 BOPD, including condensate, (World Oil, March 1993). The consumption rate, Fig. 7, is about 16.9 million BOPD (Oil \& Gas Journal, December 1991). This results in the U.S. importing haif of its crude oil and significant quantities of refined products to meet current demand for liquid fuels. More thorough discussion of imports and domestic production have been described by Olsen and Ramzel (1992) based on data from Oil \& Gas Journal Energy Statistics, (1992) and EIA, Petroleum Supply Annuals, $(1991,1992)$.

Demand by the U.S. public requires that refineries convert their crude oil feed to a variety of products. Gasoline (43\%), aviation fuels $(9 \%)$, and fuel oils including diesel $(25 \%)$ constitute most of the refined product mix (EIA, Petroleum Supply Annual, 1991, 1992). With heavy oil export demands nominal, and domestic need for asphalt and other "unrefined" uses of heavy oil at a minimum, increases in heavy oil production will necessitate a corresponding refining capacity increase, and thus refinery capacity and utilization rates need to be considered. 


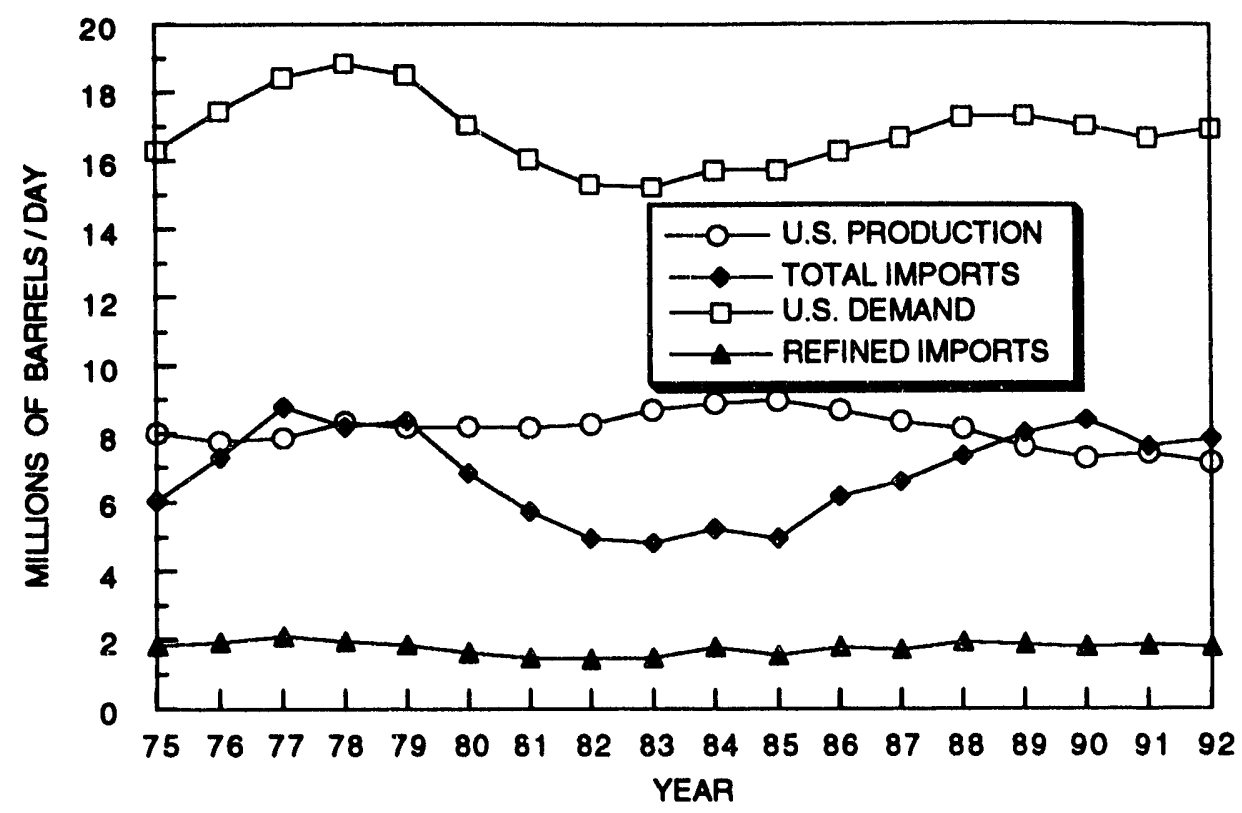

FIGURE 7. - U.S. crude oil consumption, domestic oil production, and imported crude and refined products.

Currently, U. S. refineries are running at about $88 \%$ of capacity, and we import nearly 2 million BPD of refined product (Olsen and Ramzel, 1992; EIA, Petroleum Marketing Annual, 1990). The 1991 throughput of U.S. refineries was approximately 13,500,000 BPD, of which $1,300,000$ BPD are estimated to be heavy oil based upon 1992 EIA data:

\section{BOPD}

Domestic heavy oil: $\quad<20^{\circ} \mathrm{API}$

750,000

Imported heavy oil: $\quad<20^{\circ} \mathrm{API}$

153,000

$40 \%$ of $20-25^{\circ}$ API $(925,000)$

$$
\frac{370,000}{1,273,000}
$$

Because of the high viscosity of heavy oils, particularly in the case for mos heavy oils of less than $16^{\circ}$ API gravity, heavy oil must be blended with light diluent (light cruse oil, naphtha, etc.) to meet requirements for transport or the oil must be heated and transported hot. Typical pipeline specifications call for viscosity of the oil to exceed that of most $21^{\circ}$ API gravity crude oils. Thus, about $40 \%$ of the 925,000 BOPD reported by EIA as 1991 import crude within the $20^{\circ}-25^{\circ}$ API gravity range can be considered a blend. This blended imported oil comes principally from Canada (to PADD 2) and Venezuela and Mexico (to PADD 3). 
Figure 8 shows the trends in imported crude by API gravity range. While some API gravity ranges exhibit little change since 1980 , the $20^{\circ}-25^{\circ}$ API gravity range showed growth in the early 1980 s while the $30^{\circ}-35^{\circ}$ API gravity range showed a marked decrease. This corresponded with increased heavy oil processing capacity brought about by investment in heavy oil refining capacity in the California, the Midwest and Gulf Coast region during the late 1970s and early 1980s. The trend within these API gravity ranges began to reverse after the 1986 drop in oil prices due to the increasing availability of inexpensive light oil principally from the Mideast. Figure 9 shows the drop in API gravity and stabilization during the last half of the 1980's which has extended into the 1990s. The figure highlights the increasing sulfur content of the oil refined in the U.S. which is at odds for the push to cleaner transportation fuels.

The aforementioned feedstock trends are not in themselves descriptive of the capacity of our refining industry to refine heavy oil. Quite clearly, however, the trends do suggest that the overall refining industry is geared to handle an average crude quality level of about $30^{\circ}$ API gravity and $1.1 \%$ sulfur. How well it is equipped to handle an increase in heavy oil as would be anticipated at the Case 1 projected production levels, let alone a Case 2 level, is in question.

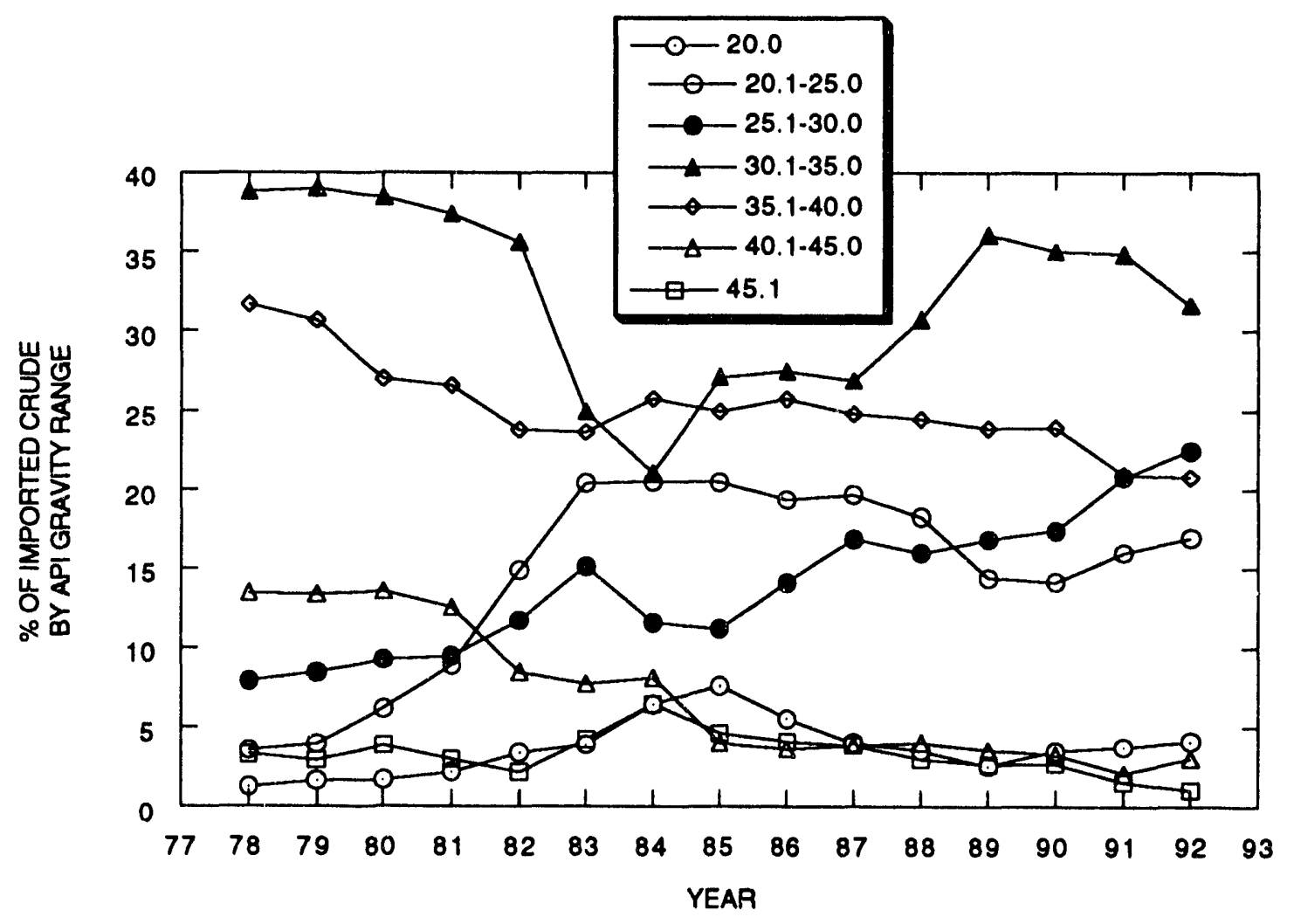

FIGURE 8. - Percent of total imported oil by API gravity. 


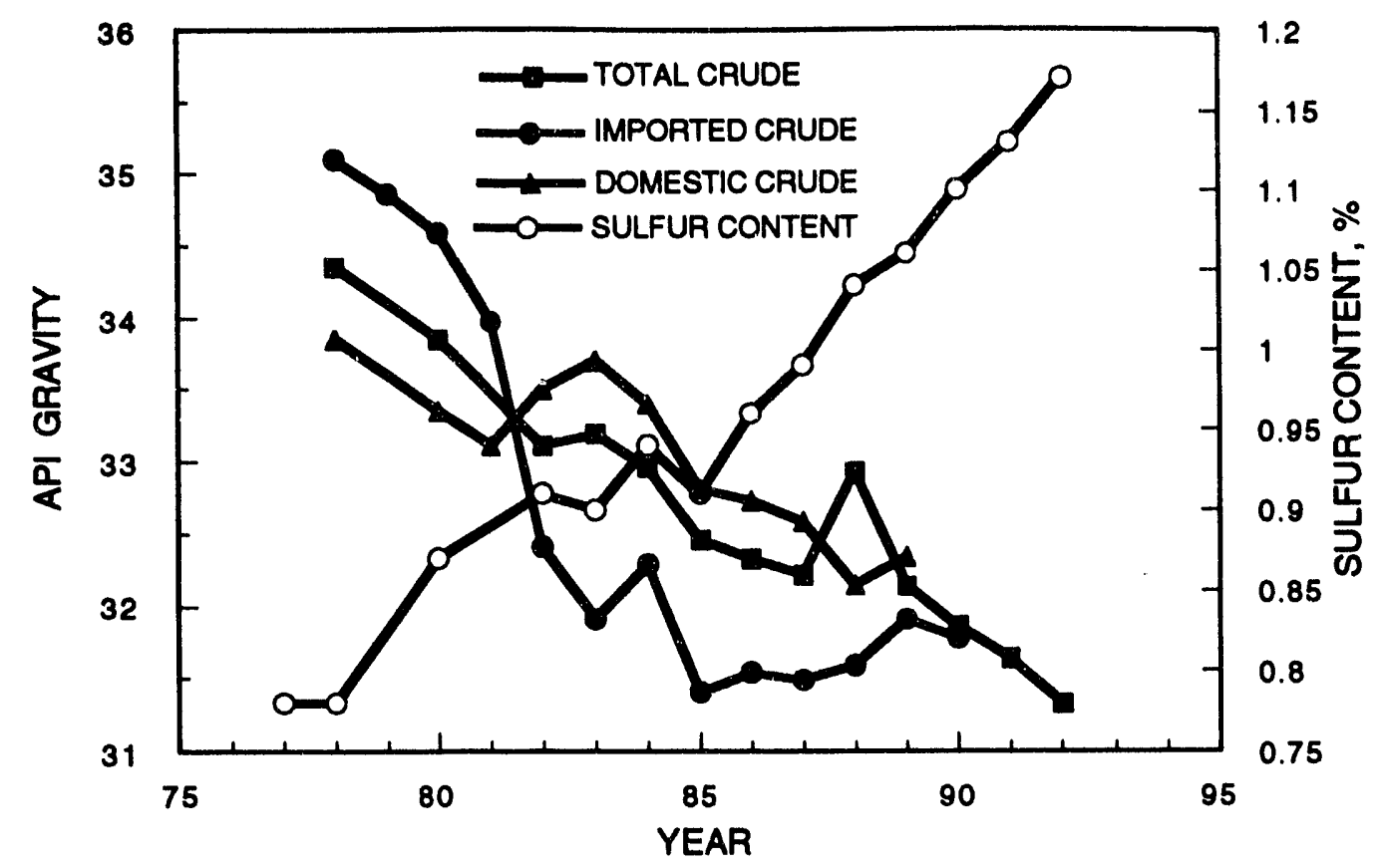

FIGURE 9. - U.S. refinery crude feedstock API gravity and sulfur content.

Assuming total consumption and import qualities remaining approximately the same level, a 500,000 BOPD increase in heavy oil production would increase the heavy oil proportion of the total refinery throughput to $13 \%$, a 900,000 BOPD increase to $16 \%$ and an average Case 2 level to well over $20 \%$. Moreover, this assumes our refinery capacity remains steady, something not at all clear.

The impact of these increases in domestic heavy oil on the U.S. refining industry have been examined and is the subject of a NIPER report (Olsen, Ramzel, Strycker, Guariguata and Salmen, 1993) being prepared by NIPER and Bonner and Moore Management Science (Houston refining consulting company.)

\section{Refinery Trends and Changing Oil Product Requirements}

Since the tumultuous 1970's when oil regulations were in force, including those favoring the allocation of cheaper domestic crudes to older small refineries, the number of U.S. refineries has dropped to less than 200 , and further decline is to be expected. This decline has been most significant among small- to medium-sized Midcontinent refineries. These refineries are old and designed to process local, sweet, light crude oil. Domestic light sweet crude oil production is declining at a faster rate than light sour crude production, and this will impact local refiners. Only those large refineries with secure long-term crude supplies will be operating in the year 2010. A significantly larger fraction of existing refineries at that time will be processing foreign crude with 
operations specifically tailored to a select imported crude. Environmental pressure within the U.S. will restrict construction of new grass-root refineries. A major grass roots refinery has not been constructed in the U.S. since the mid-1970s. Expansion and modification of existing refinery complexes or importing additional refined products will be alternatives.

The refineries that remain in the future, moreover, will be markedly different in product slate and refining complexity than the case in the 1970's. In large part this reflects changes brought about by the 1970 Clean Air Act and the 1990 Amendments to the Clean Air Act. Because of these, the composition of transportation fuels has changed significantly.

In the 1970s, the gasoline pool was totally hydrocarbon-based along with additives such as lead antiknock/antiwear agents. Today, the gasoline pool contains very little lead, but the 1990 Amendments to the Clean Air Act require large volumes of oxygenates such as methyl tertiary butyl ether (MTBE), ethanol, tertiary amyl methyl ether (TAME) or ethyl tertiary butyl ether (ETBE) to meet minimum oxygen content levels in reformulated motor gasoline. By November 1992, gasoline with a minimum oxygen content of $2.7 \%$ (winter standard) had to be sold in approximately 40 cities not in compliance with the Environmental Protection Agency's carbon monoxide and/or ozone standards. If MTBE is the only oxygenate, then $15 \%$ by volume is needed to meet minimum oxygen content of $2.7 \%$ (Unzelman, 1991). The summer standard for oxygen content for these areas will be $2.0 \%$. In addition, other areas that are not official non-compliance zones have the ability to "opt-in(to)" the reformulated fuels.

The 1990 Amendments to the Clean Air Act also address many other fuel parameters other than oxygen content such as Reid Vapor Pressures (RVP) and volatile organic compounds (VOCs), benzene content and other aromatics (heavy oil typically has more aromatics than light oil), certain toxic compounds, etc. The second largest volume refinery product (highway diesel fuel) has to have a sulfur content of less than $0.05 \mathrm{wt} \%$ by October 1993, which is a dramatic reduction from current levels. Reduced aromatic content and cetane index restrictions will also apply to highway diesel fuel.

With the intense demand for restructuring/rebuilding U.S. refineries to meet the provisions of the 1990 Amendment to the Clean Air Act, and easy-to-refine, high margin, light oil imports readily available, little petroleum investment is being directed to construction of additional cokers (fluid or delayed), hydrocrackers, or hydrogen generation facilities to process additional domestic heavy oil. Moreover, of the investment going into heavy oil refining of late, most is being dedicated to imported rather than domestic heavy oil.

\section{California Oil Production Experience and Outlook}

Beyond the refinery capacity question is the second concern, that of crude oil price stability.

The Case 1 projections presented earlier show expansion of California heavy oil production by 100,000 to 300,000 BOPD under each of the three production scenarios. This is only about a third 
of each of the total projection levels, and may seem low relative to California's almost $90 \%$ share of the present 750,000 BOPD heavy oil production in the U.S. However, despite California's' large resource base, analysis of the data from the past few years does not support such a large share in the projected growth.

Of particular concern is the price differential between West Texas Intermediate and Kern River crude oils as was shown in Table 2. If it were to remain at two-thirds over the projection period (1990 - 2010) of this study, it would discourage investment in California heavy oil and skew the heavy oil production to areas other than California where heavy oil would be priced closer to that of WTI. Figures 10 and 11 show the trends in California heavy oil production over previous decades. These show an increase in heavy oil as a share of total oil production from $20 \%$ in the 1940 s to $70 \%$ in the 1980 s. Growth in heavy oil halted in the mid-1980's, as shown in Figure 10. Total oil production has peaked in each of the three heavy oil producing areas (Conservation Committee of California Producers, 1986-1990). Los Angeles Basin production peaked in the late 1960's. The Coastal region oil production increases during times of higher oil prices but has been steadily declining in spite of having great offshore oil production potential. Production grew in the San Joaquin Valley grew during 1970's and early 1980's due to open up of Elk Hills and the cyclic steam and steam flooding that was implemented in the heavy oil fields of the Valley. Production has been declining since the drop in oil prices in 1986. Resumption of

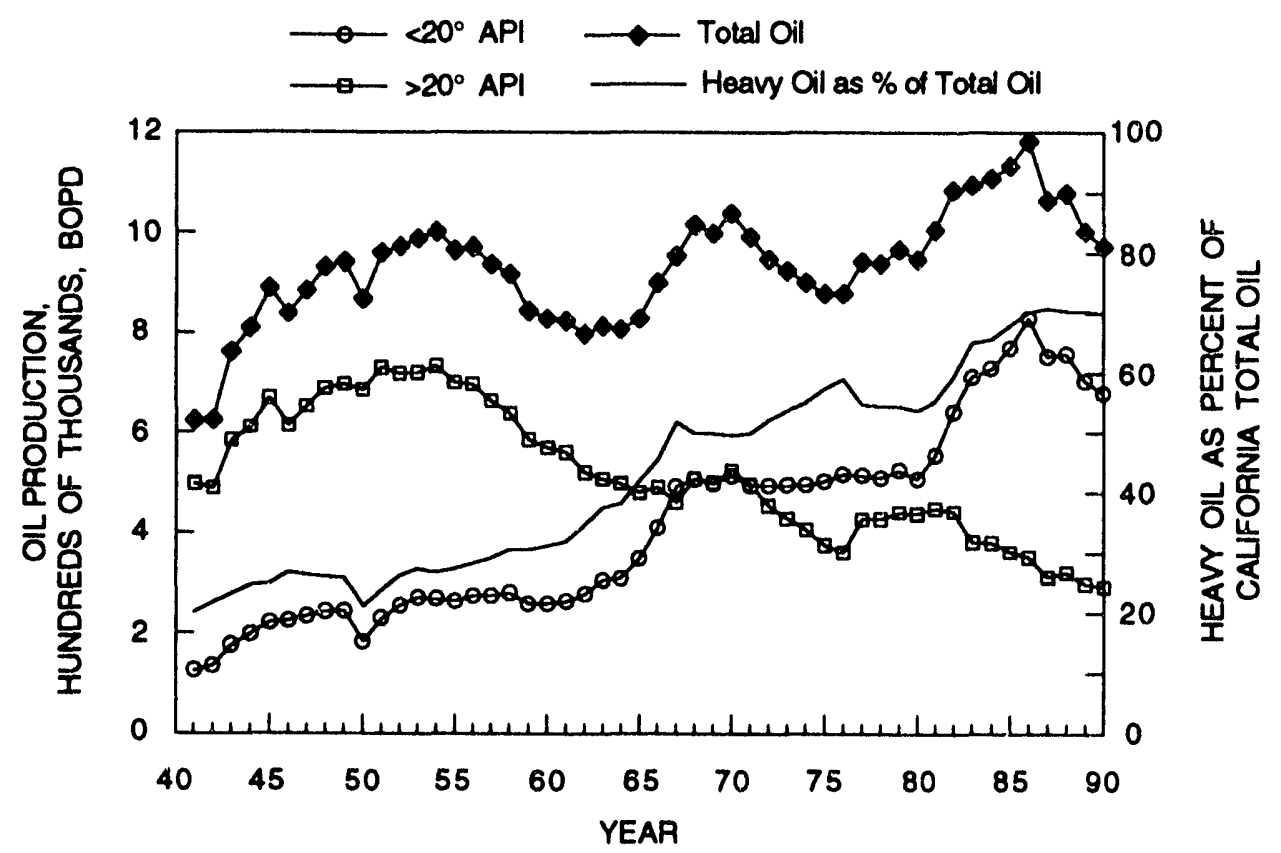

FIGURE 10. - California oil production since 1940 showing the percent of total oil that is heavy oil. 


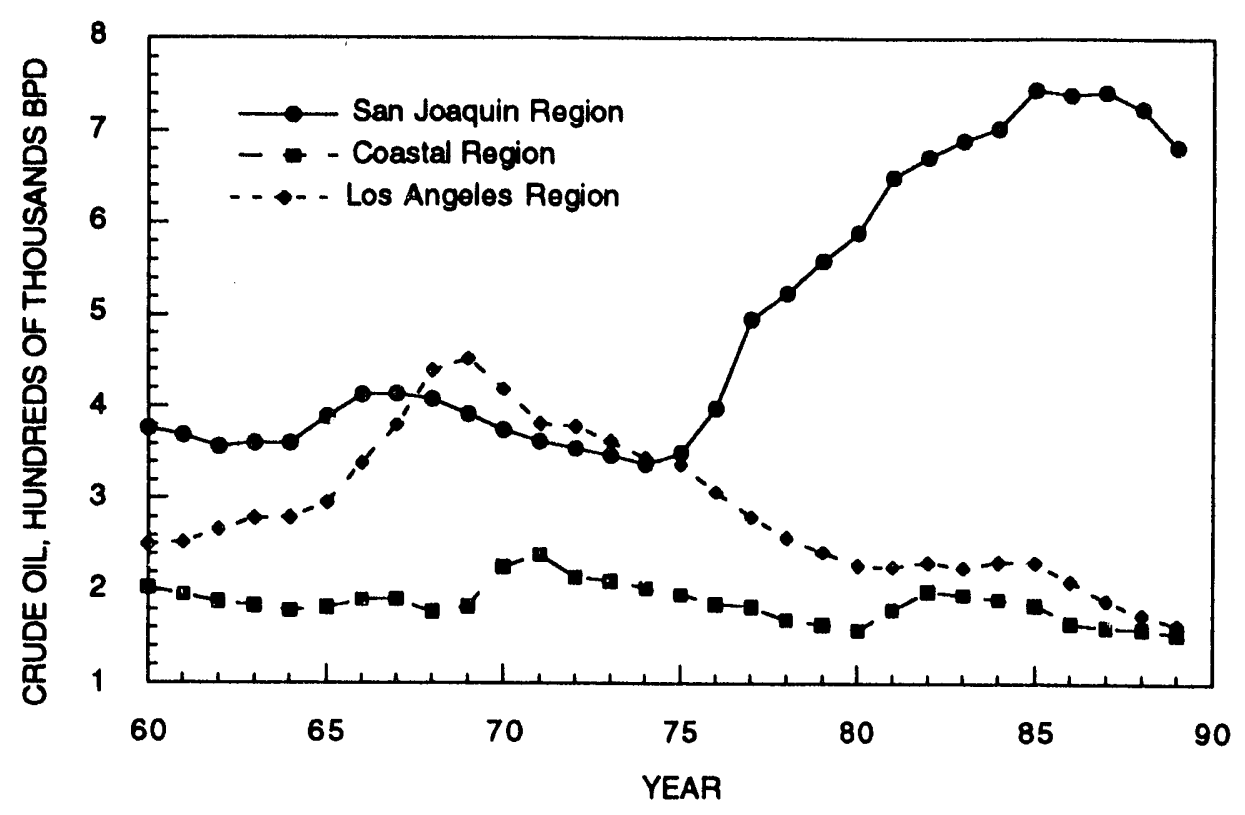

FIGURE 11. - Total oil production by regions within California.

growth in heavy oil production in California will require conducive market prices and investment conditions. The lead times for development of a heavy oil field are long and the costs are high. It has taken nearly 30 years for the current 500,000 BOPD of EOR heavy oil production to be developed in California. Mobil Oil's recent expansion program to add 50,000 BOPD to production by adding to its own existing infrastructure (adjacent Mobil properies within the same producing interval, known production technology, permits for steam generators, heated pipeline to refinery, and refinery capable of processing this heavy crude) reportedly cost $\$ 1$ billion (Enhanced Recovery Week, 1990). Development of the heavy oil resources as shown in Tables 3-5 would be through increments of thousands of barrels. Lead times of 1 to 3 years would be required before the first oil production and the first major production would come from cyclic steam. California has shown that with the necessary investment in heavy oil such as occurred in the late 1970's and early 1980's that heavy oil production and jobs associated with expanded heavy oil (production and refining) are achievable.

Since 1986, oil price performance of the world oil market has been one of the greatest challenges to increasing domestic heavy oil production. That challenge is to overcome the effects of unstable crude oil prices on production. The 1986 California posted field price for Kern River $13^{\circ}$ API gravity oil, the benchmark heavy oil, fell to less than $\$ 8.00 / \mathrm{bbl}$. This price, due to a 
worldwide excess of light crude oil, resulted in drastic efforts to reduce expenses by California heavy oil producers, as well as light oil producers in the U.S. and abroad. For a brief period during the Gulf War in 1991, the Kern River oil price climbed above \$20/bbl. In January 1992, the California posted field price for Kern River $13^{\circ}$ API crude was only $\$ 10 / \mathrm{bbl}$, and the North Slope posted field price for Alaskan North Slope (ANS) $27^{\circ}$ API crude oil was $\$ 9.50 / \mathrm{bbl}$. By the summer of 1992, a period of temporary worldwide supply restriction, the price for Kern River crude was $\$ 16.50 / \mathrm{bbl}$. By December 1992, the supply restriction had disappeared, and Kern River crude was back down to $\$ 11.50 / \mathrm{bbl}$. This price/marketing instability constraint plays havoc with heavy oil production investment plans. The posted price for Kern River oil is shown in figure 4 (Oil \& Gas J., 1980-1993). Investment requires confidence in future price levels. Recent price swings are less than encouraging. The recent addition of Point Arguello heavy oil to California supplies appears to make the market even more fickle, and prices have decreased when Arguello production exceeds 30,000 BOPD (Hankins, 1991).

Additional factors in the world market, including plentiful light oil from the Middle East will continue to depress the world oil price, or at least keep it from rising significantly. OPEC has the ability to control world oil prices to meet their proposed pricing structure of $\$ 28 / \mathrm{bbl}$ in the year 2000 and $\$ 35 / \mathrm{bbl}$ in 2010. (in constant dollars: Keynote address to AAPG in 1991 by President of OPEC). If the historical trend for crude oil pricing holds through the next two decades, which is doubtful, then Kern River $13^{\circ}$ API crude oil could be selling as low as half to two-thirds of West Texas Intermediate (i.e., heavy oil will be $\$ 14.00$ to $18.50 / \mathrm{bbl}$ in the year 2000 and $\$ 17.75$ to $23.10 / \mathrm{bbl}$ in 2010). This exceeds the historical gap between heavy and light oil prices of $\$ 5-7 / \mathrm{bbl}$ since thermal production really gained a foothold in Southern California. In recent years, this gap has been increasing, and in light of ample light oil available through imports and increasing demand for cleaner fuel, this margin between light crude and heavy crude (gap) could very well increase.

\section{CONCLUSION}

The following observations and conclusions are based upon data analyzed and presented in part in this report and in the series of publications on the feasibility of increasing heavy oil production in the United States. Projections were made to meet production goals of an additional $(900,000 ; 500,000$; and 300,000 BOPD) heavy oil above the current production of 750,000 BOPD. The 900,000 BOPD level was chosen to match previous predictions which were part of the 1991 National Energy Strategy, while the lower production levels were developed as more achievable increments. California has significant potential future heavy oil production capabilities but the market is constrained by plentiful medium gravity oil and by the high cost of transporting excess heavy oil to the Gulf Coast for refining. The U.S. Gulf Coast states have a large, mostly 
untapped potential for future incremental heavy oil production. Many of the reservoirs are Tertiary age, shallow, unconsolidated or friable sandstone reservoirs with high oil saturation. The reservoirs typically are thinner than those in California, but have some of the same geology (turbidites and fluvial dominated deltaic). These reservoirs have not been developed because lighter oil has been available and commands a higher price. Much of the incremental Gulf Coast heavy oil production will be by thermal means and will require diluent for transport in the absence of a heated pipeline network. As long as there is significant light oil production, there should be adequate diluent to allow transport of a mixture of heavy and light oil from the field to the refinery.

The U.S. Gulf Coast has the largest refining capacity and the largest potential for refining heavy oil outside of California. These refineries have limited capacity to process significant additional heavy oil. Since there is not an excess of heavy oil refining capacity, one might wish to consider backing out imported heavy oil and replacing it with domestic heavy oil. Complicating this however, is the fact that some of the imports of heavy oil are from foreign suppliers to their own refineries. The Gulf Coast heavy oil quality is often better (Table 7) than Californian heavy oil or some that is imported. The average gravity of heavy oil in this region is $18.4^{\circ}$ API. This is not the average gravity of heavy oil being produced at present, but a weighted average based on estimated OIP in the Gulf Coast region. The sulfur content of prospective heavy oils was obtained from a U.S. DOE crude oil database for representative reservoirs listed in NIPER's heavy oil database.

TABLE 7. - Composition of Projected Heavy Oil

\begin{tabular}{|c|c|c|c|}
\hline \multirow[b]{2}{*}{ PADD } & \multirow[b]{2}{*}{ General location } & \multicolumn{2}{|c|}{ Additional crude oil } \\
\hline & & $\begin{array}{c}\text { Range, } \\
\text { gravity, }{ }^{\circ} \mathrm{API}\end{array}$ & $\begin{array}{c}\text { Sulfur, } \\
\%\end{array}$ \\
\hline 2 & Midcontinent (KS, MO, OK) & 16 & 2 \\
\hline 2 & Remainder of PADD 2 & $16-20$ & 0.5 \\
\hline 3 & Permian Basin & $15-20$ & 2 \\
\hline 3 & East Texas & $12-18$ & $>2$ \\
\hline 3 & SE. Arkansas \& N. Louisiana & $13-20$ & 2.5 \\
\hline 3 & South Texas Basin & $18-20$ & 0.5 \\
\hline 3 & Texas Gulf Coast Salt Basin & $16-20$ & 0.5 \\
\hline 3 & Louisiana Gulf Coast Salt Basin & $16-20$ & 0.7 \\
\hline 3 & Mississippi Interior Salt Basin & $16-20$ & 0.7 \\
\hline 4 & Wyoming, Montana & $13-20$ & 2.5 \\
\hline 5 & San Joaquin Valley & $10-15$ & 1.2 \\
\hline 5 & Los Angeles Basin & $16-20$ & 1.5 \\
\hline 5 & Coastal Range California & $13-19$ & $>2.5$ \\
\hline 5 & Offshore California & $13-20$ & $>2.5$ \\
\hline 5 & North Slope, Alaska & $14-20$ & $>1.5$ \\
\hline
\end{tabular}




\section{SUMMARY}

Heavy oil resources exist in the U.S. and the technology is available to develop much of the resource, although some heavy oil resources are produced more economically than others. One of the major market constraints for the development of the resource is oil price. Heavy oil production, transportation, and refining costs are significantly more per barrel than light oil. In a free market, refiners are free to purchase higher quality domestic or imported light and medium crude oils that as a rule have fewer production, transportation, and refining problems than heavy oil. Therefore, heavy oil (domestic or foreign) is priced lower than these crude oils.

In the current free market, investment opportunities in other countries for the development of light, medium and heavy oil are increasingly giving a better rate of return. If the U.S. heavy oil resource is to be developed, investment incentives for production, transportation, and refining are needed. A major increase in heavy oil production would sharply reduce the decline in U.S. oil production. Development of the U. S. heavy oil production, transportation, and refining infrastructure, if accompanied by the proper incentives, could create a substantial number of jobs and profitable investment opportunities.

In summary, there are burdens placed on the heavy oil production and refining industry that inhibit development of the U. S. heavy oil resource. This resource is not speculative but real and producible. The right mix of technology and production incentives can stimulate the industry and are required to bring about significant heavy oil production in the U.S.

\section{ACKNOWLEDGMENTS}

This work was sponsored by the U.S. Department of Energy under cooperative agreement DE-FC22-83FE60149 as part of DOE project SGP37, Feasibility Study of Heavy Oil Recovery. The author wishes to thank W. I. Johnson and E. B. Ramzel for their contributions to defining the heavy oil resources and some of the constraints to heavy oil production; A. Strycker, Bill Linville and M. K. Tham, all of NIPER; W. D. Peters, M. R. Ray and T. B. Reid of the DOE Bartlesville Project Office for their review and R. A. Avellanet, DOE, for his counsel and critical review.

\section{BIBLIOGRAPHY}

Alaska Department of Natural Resources, Oil \& Gas Division, Individual Well Production for 1991, Conoco Milne Point Unit, July 8, 1992, Anchorage, Alaska.

Alaska Oil and Gas Conservation Commission, Statistics Division, Schrader Bluff reservoir of Milne Point Unit, February 18, 1993, Anchorage, Alaska. Personal communication with David Olsen, NIPER.

Brashear, J. , M. Godec, and B. Wood: (ICF Resources) memorandum to Folstein, R. (DOE), dated May 3, 1991 on Incremental Oil Production Autributable to the Oil Research Program.

Conservation Committee of California Oil Producers. Annual Review of California Oil \& Gas Production 1990, Los Angeles, CA, 1991. 
Conservation Committee of California Oil Producers. Annual Review of California Oil \& Gas Production 1989, Los Angeles, CA, 1990.

Conservation Committee of California Oil Producers. Annual Review of California Oil \& Gas Production 1988, Los Angeles, CA, 1989.

Conservation Committee of California Oil Producers. Annual Review of California Oil \& Gas Production 1987, Los Angeles, CA, 1988.

Crysdale, B. L. and C. J. Schenk: Heavy Oil Resources of the United States, U. S. Geological Survey Bulletin $1885,1990$.

Dietzman, W. D., M. Carrales Jr., and C. J. Jirik, Heavy Crude Oil Reservoirs in the United States - A survey:, U.S. Bureau of Mines Information Circular 8263, 1965.

Energy Information Agency. Annual Outlook for Oil and Gas 1990, Office of Oil and Gas, Publication No. DOE/EIA 0517(90), May 1990.

Energy Information Agency. The U.S. Petroleum Refining Industry in the 1980's, Office of Oil and Gas, Publication No. DOE/EIA 0536, October 1990.

Energy Information Agency. Annual Energy Outlook 1991 with Projections to 2010, Office of Energy Markets and End Use, Publication No. DOE/EIA 0383(91), March 1991.

Energy Information Agency. Annual Energy Outlook 1993 with Projections to 2010, Office of Integrated Analysis and Forecasting, Publication No. DOE/EIA 0383(93), January 1993.

Energy Information Agency. Petroleum Marketing Annual 1991, Office of Oil and Gas, Publication No. DOE/EIA 0487(91), August 1992.

Fancher, G. H. and D. M. Mackay: Secondary Recovery of Petroleum in Arkansas - A Survey, Report to the 56th General Assembly of the State of Arkansas, El Dorado, AR, 1946.

Gill, D.: "Kern County," Oil \& Gas Investor, August 1990, pp. 14-27.

Grigsby, E.: "Paper and Pencil Exercise or Treble Damages in Kern County by D. Gill," Oil \& Gas Investor, August 1990, p. 19.

Group of Experts: UNITAR Proposal for the Definition of Heavy Crude and Tar Sands and Addendum, Second International Conference on Heavy Oil and Tar Sands, Caracas, Venezuela, February 1981.

Interstate Oil Compact Commission: Major Tar Sand and Heavy Oil Deposits of the United States, Oklaijoma City, OK, 1984.

Kujawa, P.: Heavy Oil Reservoirs Recoverable by Thermal Technology, Annual Report, U. S. DOE Fossil Energy Report DOE/ET/12380-1, Volumes 1-3, February 1981.

Maples, J. W.: Kern County Assessor, Kern County, California. Oil and Gas Properties Appraisal Parameters, 1990-1991, March 1990.

Maples, J. W.: Kern County Assessor, Kern County, California. Comparison of Kern River and West Texas Intermediate Annual Oil Prices, January 1993.

Mefferd, M. G., California Department of Conservation: Division of Oil \& Gas, 76th Annual Report of the State Oil \& Gas Supervisor, 1990, No. PR06. 
Mefferd, M. G., California Department of Conservation: Division of Oil \& Gas, 75th Annual Report of the State Oil \& Gas Supervisor, 1989, No. PR06.

Mefferd, M. G., California Department of Conservation: Division of Oil \& Gas, 74th Annual Report of the State Oil \& Gas Supervisor, 1988, No. PR06. Thrash, L. S.: Annual Refining Survey. Oil \& Gas Journal, v. 88, no. 13, March 26, 1990, pp. 77.

Moritis, G.: Biennial EOR Production Report, "CO 2 and HC Injection Lead EOR Production Increase," Oil \& Gas Joumal, April 23, 1990.

Moritis, G.: Biennial EOR Production Report, "EOR Increases 24\% Worldwide;' Claims 10\% of U.S. Production," Oil \& Gas Journal, April 20, 1992.

National Energy Strategy: Powerful Ideas for America. First Edition 1991/1992, Washington, DC, February 1991.

National Petroleum Council. Enhanced Oil Recovery, National Petroleum Council, June 1984.

Nehring, R., R. Hess and M. Kaminski: The Heavy Oil Resources of the United States. Prepared for U.S. DOE R2946-DOE, published by the Rand Corporation, September 1983.

Oil \& Gas J.: U.S. Crude Prices in Oil \& Gas J. Weekly Production Report, 1980-1992.

Oil \& Gas J.: U.S. Crudc Oil Prices in Oil \& Gas J, Weekly Production Report, January 20, 1992, p. 71.

Oil \& Gas J.: Survey of Operating Refineries in the U.S. (state capacities as of January 1, 1993) Oil and Gas J. Data Book, 1993 Edition, PennWell Books, Tulsa, OK, p. 208.

Olsen, D. K.: (NIPER) memorandum to A. Strycker (NIPER), dated December 26, 1991 on Projected Additional Heavy Oil to the Year 2010.

Olsen, D. K. and E. B. Ram7el: Heavy Oil Refining and Transportation: Effect on the Feasibility of Increasing Domestic Heavy Oil Production, presented at the 1991 Eastern Heavy Oil Shale/Tar Sands/Heavy Oil Symposium, Lexington, KY, November 13-15, 1991. Published in the proceedings pp. 58-70, April 1992. FUEL, V 71 No. 12, December 1992, pp. 1391-1.401.

Olsen, D. K., W. I. Johnson and E. B. Ramzel: Feasibility Study of Heavy Oil Recovery in the Lower 48 States, U. S. Department of Energy Report No. NIPER-521, January 1991.

Olsen, D. K. and W. I. Johnson: Feasibility of Heavy Oil Recovery in the Midcontinent (Kansas, Missouri, Oklahoma) U.S. Department of Energy Report No. NIPER-560 in review.

Olsen, D. K. and W. I. Johnson: Feasibility of Heavy Oil Recovery in the Permian Basin (Texas and New Mexico). U.S. Department of Energy Report No. NIPER-578, March 1993.

Olsen, D. K., E. B. Ramzel and R. A. Pendergrass II: Trends in Heavy Oil Production and Refining in California, U. S. Department of Energy Report No. NIPER.587, February 1992.

Olsen, D. K., E. B. Ramzel and R. A. Pendergrass II: Recent Trends in Heavy Oil Production and Refining in California, Preprints of Symposium on EOR, American Chemical Society, Denver, CO, March 28-April 2, 1993, v 38, No. 1, February 1993, pp. 198-205.

Olsen, D. K., E. B. Ramzel, A. Strycker, G. Guariguata and F. G. Salmen: Projections of the Impact of Expansion of Domestic Heavy Oil Production on the U.S. Refining Industry, 1990 to 2010, U. S. Department of Energy Repon No. NIPER-620, February 1993 in review. 
Olsen, D. K., E. C. Taylor and S. M. Mahmood: Feasibility Study of Heavy Oil Recovery-Production, Marketing, Transportation and Refining Constraints to Increasing Heavy Oil Production in Alaska, U.S. Department of Energy Report No. NIPER-610, December 1992.

Park, W. G. S. O. Wood, Jr., and M. Carrales Jr.: Heavy Oil Reservoirs in Arkansas, U.S. Bureau of Mines Information Circular 8428, 1969.

Peeples, J. E.: The Clean Air Act, A Brave New World for Fuel Reformulation, Fuel Reformulation, v. 1, no. 1, September/October 1991, pp. 27-31.

Piper, E. M., A. W. Riddel and R. H. Trent: An Evaluation of Heavy Oil Mining, U.S. Department of Energy Report No. DOE/PC/30259-1. v. 1, March 1983, pp. 190-244.

Scherr, R. C., G. A. Smalley Jr., M. E. Norman: Clean Air Act Complicates Refinery Planning, Oil \& Gas J., May 27, 1991, pp. 68-75.

Swain, E. J.: Major Growth in Coke Production Takes Place, Oil \& Gas Journal, May 6, 1991, pp. 100-102.

Thomas, C. P., T. C. Doughty, D. D. Faulder, W. E. Harrison, J. S. Irving, H. C. Jamison and G. J. White: Alaska Oil and Gas: Energy Wealth or Vanishing Opportunity? U.S. Department of Energy Report No. DOE/D/01570-HI, January 1991.

Thrash, L. S.: Annual Refining Survey. Oil \& Gas Journal, v. 89, no. 11, March 18, 1991, pp. 84.

Unzelman, G. H.: The Fuel Revolution Continues, Fuel Reformulation, v. 1, no. 1, September/October 1991, pp. 32-35.

Wells, J. S.: Inventory of Heavy Oil in Western Missouri, U. S. DOE Fossil Energy Report BETC-1808-1, September 1979.

World Oil, Industry at a Glance, World Oil, March 1993, p. 17. 

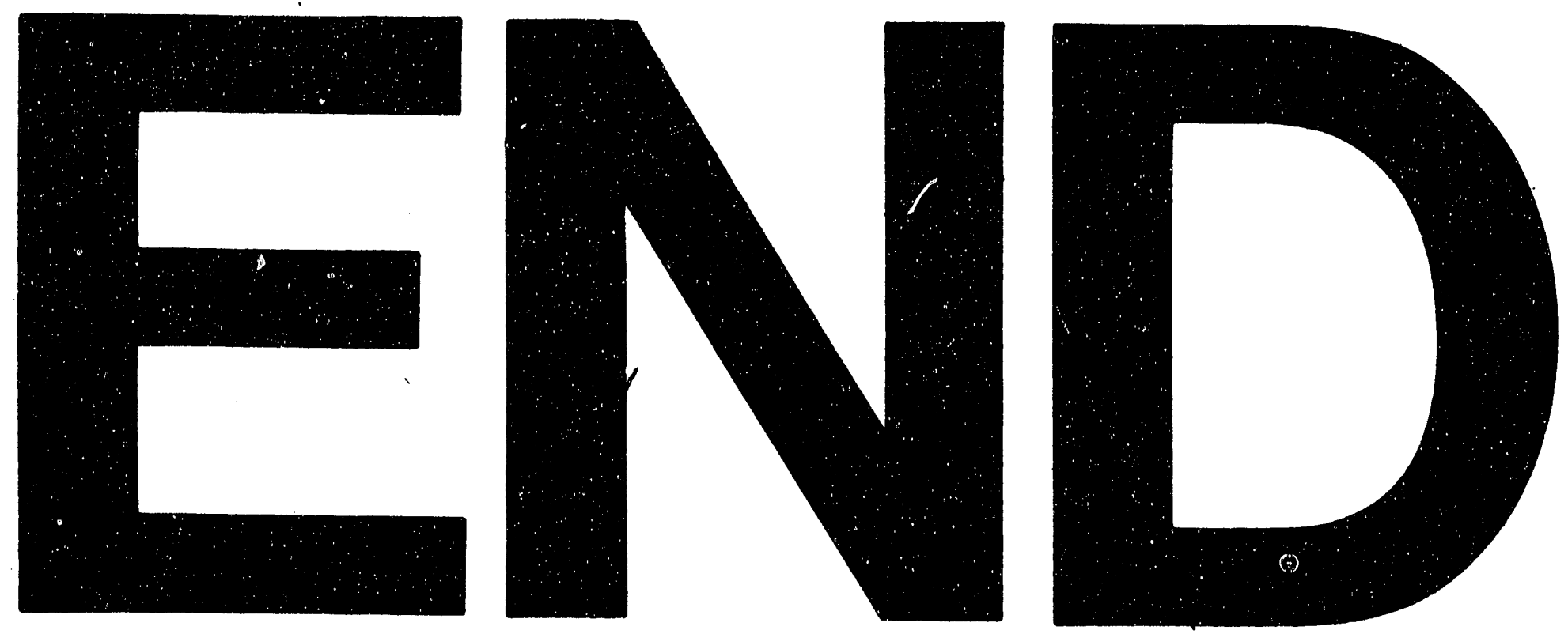

p.
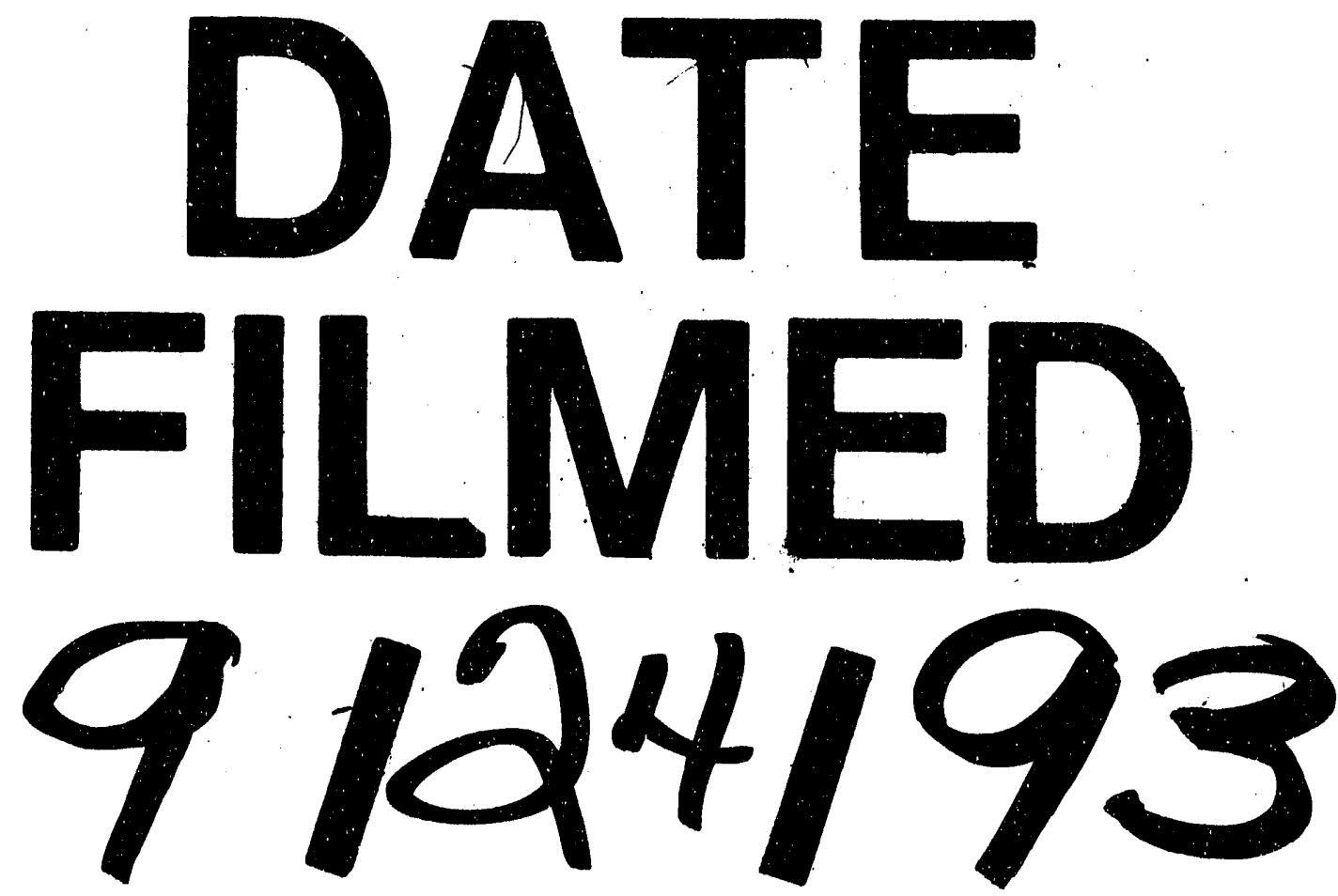
